\title{
The Bar Fight Theory of International Conflict: Regime Type, Coalition Size, and Victory*
}

\author{
BENJAMIN A.T. GRAHAM, ERIK GARTZKE AND CHRISTOPHER J. FARISS
}

\begin{abstract}
T tudies of regime type and war show that democracies tend to win the wars they fight, but questions remain about why this is the case. A simple, if underappreciated, explanation for democratic success is that democracies fight alongside larger and more powerful coalitions. Coalition partners bring additional material capabilities and may also provide intangible benefits to the war effort, such as increased legitimacy or confidence. Democracies may also find it less costly to join coalitions, as democratic war aims may be easier to apportion among the victors without diluting the spoils. Evaluating our hypotheses in a sample of all wars (or all militarized disputes) during the period 1816-2000, we find that democracies fight alongside larger coalitions and that states fighting alongside larger coalitions are more likely to win major contests. Coalition size subsumes most (and in some specifications all) of the direct effect of regime type on victory.
\end{abstract}

1

large body of research identified, and then sought to explain, the tendency for democracies to win wars. The effect is large-democracies win almost all the wars they start and about two-thirds of the wars in which they are targets of aggression (Reiter and Stam 2002). While democratic victory has achieved the status of conventional wisdom, the field continues to struggle to understand why this is so.

The effort to understand democratic victory naturally began at the state level, where democratic attributes reside. For example, democratically elected politicians might be more resolute because they pay a higher price for the failure of their foreign adventures (Bueno de Mesquita et al. 1999; Bueno de Mesquita et al. 2003). Democracies may possess better motivated and more skillful soldiers (Reiter and Stam 1998), or they may be more adept at marshaling the resources necessary to prevail (Lake 1992; Valentino, Huth and Croco 2010). Alternately, democracies may be more astute in their selection of contests, choosing only those they are likely to win (Reiter and Stam 1998; Reiter and Stam 2002). Another set of explanations derives from the social/international setting within which democracies operate. Choi $(2003 ; 2004 ; 2012)$ argues that democracies tend to co-ally and are more effective alliance partners than non-democracies.

While plausible, all these theories ignore a simple possibility, one that should be considered even in the presence of other causal mechanisms. Democracies may or may not win wars because of their own qualities-because of what they are or what they do-or because of the

\footnotetext{
* Benjamin A. T. Graham is an Assistant Professor in the Department of Political Science, University of Southern California, 3518 Trousdale Pkwy Von KleinSmid Center 330, Los Angeles, CA 90089-0043 (benjamin.a.graham@usc.edu). Erik Gartzke is a Professor in the Department of Political Science, University of California, San Diego 9500 Gilman Drive/Office 327 SSB, 0521 La Jolla, CA 92093-0521 (egartzke@ucsd.edu). Christopher J. Fariss is a Jeffrey L. Hyde and Sharon D. Hyde and Political Science Board of Visitors Early Career, Professor in Political Science and Assistant Professor in the Department of Political Science, Pennsylvania State University, 200 Pond Lab, University Park, PA 16802 (cjf0006@ gmail.com). The authors would like to thank the participants of the 2011 meeting of the International Studies Association and the 2010 meeting of the International Studies Association West. To view supplementary material for this article, please visit http://dx.doi.org/10.1017/psrm.2015.52
} 
qualities of their allies. It is also possible, however, that democracies prevail due to quantity (not quality), by fighting alongside a larger number of countries in most of their contests. Having more comrades in a fight must often prove to be an advantage, one that is likely to be valuable regardless of regime type. The biggest martial asset of democracies may well be that they are better at making friends, not that they are better at vanquishing their enemies. ${ }^{1}$

We begin our "quantity" theory of democratic victory with the insight that the domestic incentives confronting political leaders differentially affect the costs and benefits of forming international coalitions to prosecute a war. ${ }^{2}$ While both democracies and non-democracies have an obvious interest in victory, democracies are better able to make war collectively. Autocracies, with the small winning coalitions highlighted by the literature, tend to seek private benefits from fighting. A thirst for private goods means that autocracies optimize at a smaller coalition size to avoid diluting the spoils of war. Democracies, in contrast, already supply public goods to large domestic winning coalitions. They therefore gravitate toward war aims that are less adversely affected by the number of allies or participants. Objectives such as enforcing norms or advancing ideologies allow coalition members to share in the fruits of victory without diluting the payoffs available to other participants.

This contrast may help to explain, for example, the huge disparity between the number of Allied and Axis powers during World War II. For example, within this conflict, Canada, Australia, and New Zealand, all democratic states in 1939, chose to join Britain in September 1939 to fight Germany. Each of these countries made many important contributions to the eventual allied victory, especially in the North African campaign and the D-Day landing. Importantly for our argument, these countries, along with the other allied powers, shared in the public benefits of the eventual allied victory. ${ }^{3}$ Similarly, while Saddam Hussein chose to "go it alone" in invading Kuwait in 1990, the US-led coalition opposing him included no less than 32 countries. Saddam could have improved his chances of deterring the US-led coalition by creating his own alliance. However, this would presumably require sharing the spoils of war with others, diluting the very payoff that motivated Saddam to conquer Kuwait. The United States, in contrast, could share the public benefits of victory-including re-asserting territorial integrity, re-imposing the status quo and realizing various forms of solidarity-without these benefits becoming watered down. ${ }^{4}$ It could even allow participants in the coalition to have different objectives, as long as these did not involve territory or plunder. No doubt, the United

\footnotetext{
${ }^{1}$ The more comrades one has in a bar fight, the more likely one is to emerge from the brawl victorious. The virtues of the combatant matter only in so far as they relate to the ability to bring more friends to the bar than the antagonist. This analogy motivates our choice in title.

2 Our argument essentially externalizes, and endogenizes, the perspective pioneered by Bueno de Mesquita et al. (1999). Larger coalitions can form around the provision of (global) public goods.

3 This logic may also help to explain the intervention of the United Kingdom, France, and Finland on the side of newly independent states of Estonia, Latvia, and Lithuania, which each fought against the Soviet Union in the aftermath of World War I (Reiter, Stam and Horowitz 2014). The non-democratic states of Germany and Poland also intervened in these conflicts, first fighting against Russia but then later fighting against the forces of Latvia and Lithuania with the intention of controlling some of this contested territory (for more details, see the case notes in the online appendix of Reiter, Stam and Horowitz 2014). We would like thank one of our anonymous reviewers for suggesting these examples.

${ }^{4}$ For the 31 participants in this conflict with data, the mean Polity score is 6.29 , slightly higher than average polity in 1991. If, however, we eliminate countries in the immediate region of the conflict that have more parochial reasons to participate in the war, the average Polity score among the 22 out-of-region countries is 9.29. It should also be emphasized that the mostly democratic distant partners seemed to have no major difficulty working alongside regional autocracies, presumably because their objectives (reinforcing the status quo) were not incompatible with regional actors who might have been concerned with territory. We provide the data for this example and data and more discussion for the Korean War (1950-1953) in section 10.4 of the appendix.
} 
States would have defeated Iraq even without the assistance of other nations. Still, the ability to increase the size of a coalition should be an important military advantage.

As we show, democracies tend to go to war as members of more numerous and cumulatively more capable coalitions than do non-democracies. As we also demonstrate, states fighting alongside larger and cumulatively more powerful sets of partners tend to win the wars or disputes in which they are engaged. Finally, the penchant for democracies to fight in larger and more powerful coalitions actually accounts for much of the empirical relationship between regime type and victory and, in many specifications, subsumes any direct effect of regime type on victory. We run two separate analyses, one which operationalizes coalition size as the number of coalition partners fighting on the side of the state in question, and the other that assesses the total military capabilities of those partners. Results are consistent across both analyses. Similarly, our findings are robust to a variety of confounding effects and alternative explanations. After a brief review of relevant literature, we expand on each of these items, concluding with a discussion of key implications.

\section{DEMOCRACY AND VICTORY}

The existing literature proposes a range of mechanisms linking regime type to military victory, with the bulk of contemporary scholarship arguing that democracies are more cautious in their selection of contests, more committed or adept on the battlefield, or both. We seek to augment the explanations provided in the literature with a simple and intuitive alternative causal account. In this section, we briefly review the claims made in other theories before moving on to present our own.

Existing electoral accountability explanations suggest that leaders in democracies are more likely to be removed from office after poor performance in a contest than are counterparts who avoid such conflicts (Bueno De Mesquita and Siverson 1995; Bueno de Mesquita et al. 2003; Croco 2011). ${ }^{5}$ Democratic leaders thus have an incentive to work harder to avoid entering into conflicts they are unlikely to win.

In addition to electoral accountability, other explanations suggest ways in which democratic norms or institutions might constrain the behavior of liberal leaders (Russett 1993; Doyle 1997). Officials in democracies are said to exhibit greater respect for the rights and freedoms of their citizens as they participate in war, thereby limiting unnecessary loss of life or destruction of resources (Reiter and stam 2008). ${ }^{6}$ A reluctance to incur casualties could force democratic leaders to make more concessions to avoid fighting, so that the contests that actually occur are those where democracies are resolved. Democratic leaders may thus be forced to choose their conflicts more carefully, emphasizing disputes where victory appears assured. Finally, selection into contests could also lead to frequent victories if democracies have access to better strategic information than autocracies (Reiter and Stam 1998).

While arguments that democracies do a better job of "picking winners" are engaging and plausible, they are limited in the range of cases they can explain. ${ }^{7}$ Democracies are not just more likely to win the wars they select and start, but are also more likely to win the wars in which they are targeted (Reiter and Stam 2002). This suggests that selection is at most, only part of the explanation. To account for democratic victory in even the contests democracies do not initiate, Reiter and Stam (1998) claim that democracies exhibit a superior capacity to fight because their

\footnotetext{
5 These results are disputed (Clarke and Stone 2008). See also Goemans and Chiozza (2011).

${ }^{6}$ Kant (1972(1795)) relies on a similar framework to conclude that republics are generally peaceful.

7 There remain questions about the general equilibrium implications of arguments about selection. If democracies win wars because they only fight in victorious contests, then opponents should presumably infer from the presence of a democratic opponent that they are in considerable peril.
} 
political culture produces more skilled and dedicated soldiers who exhibit greater leadership and take more initiative. Alternatively, democracies may have a greater ability to marshal resources for the war effort and demonstrate greater resolve given citizens with more at stake (e.g., Lake 1992; Valentino, Huth and Croco 2010). ${ }^{8}$ It is also possible that the same logic of electoral accountability that drives selection into conflicts may also influence democratic leaders' choices once a conflict begins.

However, controversy persists about the source(s) of democratic acumen in combat, with researchers looking to refine existing theories or to identify additional implications of arguments to facilitate critical tests. Theories of accountability, risk aversion, and the putative abilities of democratic soldiers are all motivated by the desire to account for the puzzle of democratic victory. While democracies may, at the margin, demonstrate these advantages, there is much less of a mystery to explain if democracies simply show up to the battlefield as members of coalitions with superior aggregate capabilities. At the very least, it is necessary to determine whether democracies win wars and militarized disputes because they are better, individually, at fighting than non-democracies, or because they happen to benefit in conflict from the collective contributions of more (or more powerful) partners.

In contrast to purely state-level explanations for democratic victory, Choi (Choi 2003; Choi 2004; Choi 2012) outlines a possible contribution from social aspects of war fighting. Democracies are said to be victorious because they tend to band together, allying with other democracies, and because democracies are more effective allies within these coalitions. Choi's emphasis on the characteristics of alliance partners - namely that democracies co-ally and that democracies make better allies-is an important step in the direction that we ourselves advocate. However, her argument is not immune to criticism, even as we provide an alternative theoretical conception.

There are two critical elements of Choi's coalition "quality" argument. Both must be present for the theory to correctly predict democratic victory: democracies must be better allies and they must be more likely to ally with other democracies. If democracies make better allies, but they are no more likely to ally with other democracies than with non-democracies, then the increased wartime effectiveness of democracies will not be disproportionately associated with democracies, but would instead diffuse through all coalitions involving at least some democratic members. This would not then account for the observed tendency toward democratic victory. Similarly, if democracies are not more effective allies, then a tendency for democracies to co-ally would not produce more successful military coalitions.

Research on democratic alliance preferences initially indicated that democracies were more likely to co-ally (Siverson and Emmons 1991). However, this relationship is not robust to refinements in analysis or sample (Simon and Gartzke 1996; Lai and Reiter 2000; Gartzke and Weisiger 2014). Current thinking is that democracies co-ally, but that autocracies show a similar preference. As Lai and Reiter note, there are "sharp limits to the connection between democracy and international cooperation" (2000, 203), suggesting as well sharp limits to the claim that democracies make better allies. See also section 10.3 of the appendix to this study, where we test, and reject, the proposition that countries prefer democratic allies.

Empirical evidence connecting regime type with alliance reliability is also mixed: Leeds (2003) finds evidence that democracies are less likely than non-democracies to violate their

\footnotetext{
${ }^{8}$ Consistent with the logic of electoral accountability, democratic leaders afraid of losing office should devote more resources to fighting, increasing the chances of victory (Bueno de Mesquita et al. 2003; Valentino, Huth and Croco 2010; Croco 2011) The related notions of "wag the dog" and "gambling for resurrection," while intuitively appealing and logically coherent in both popular and sophisticated variants (Downs and Rocke 1995), has failed to achieve much support in terms of empirical validity (Levy 1993; Meernik and Waterman 1996; Leeds and Davis 1997); that is, conclusion validity (Shadish 2010).
} 
alliance commitments, while Gartzke and Gleditsch (2004) find that democracies are less reliable allies when alliance commitments require actual intervention. We further explore and contrast the evidence for the democratic coalition quality argument and our own coalition quantity perspective in a portion of the Empirical Analysis section that follows evaluation of our hypotheses (details of this analysis appear in section 10.4 of the appendix). Re-confirming evidence in the literature, we find that democracies are not more likely to form exclusive coalitions with one another and that the quality of democratic coalitions, where present, is not sufficient to account for the apparent success of coalitions that include democratic participants.

Democratic political systems have more veto players, which is said to lead to more stable policy preferences, causing democratic alliance commitments to become more reliable. Although Choi is certainly not unique in asserting that democratic preferences are more stable, this is a claim that conflicts with democratic theory. Representation does not work without re-selection and re-selection invites volatility in social preference aggregation (Arrow 1951; Downs 1957). ${ }^{9}$ Madison (1961) rested his appeal to federalism on the assertion that democracy was ever-changing and therefore immune to the tyranny that attaches to a stable majority. According to other theories of democratic victory, it is instability, in the form of leverage by citizens over their leaders, that makes democracies so successful on the battlefield. It is therefore unlikely that democracies are both more stable as allies and less stable as regimes.

Existing findings in the literature, and further evidence provided here, call into question the core assumptions of the coalition quality explanation. At the same time, one can make the social/alliance argument without reference to the quality of partners, provided that the quantity of partners can adequately compensate. In the next section, we lay out our quantity perspective: a set of explanations consistent with our expectation that democracies tend to have more coalition partners of all regime types and that it is coalition size or aggregate capabilitiesrather than the quality of alliance partners or intrinsic regime attributes-that best accounts for the observed tendency for democratic regimes to more often win at war.

\section{VICTORY BY COALITION: MORE IS BETTER}

Fighting alongside a large and powerful set of coalition partners increases a state's probability of victory (Gartner and Siverson 1996). Having more partners increases the material capabilities available to a given side, reducing the costs of fighting for each state and raising the likelihood of military success. In other contexts, scholars focus on "allies," defined as states that are bound together by formal treaty obligations. ${ }^{10}$ Because we are largely interested in only the effect that the number or capabilities of states fighting together have on military success, we focus on wartime "coalitions," defined as states that fight on the same side of a military contest, whether or not they are party to formal treaties. It may be useful to distinguish this view of wartime coalitions as strictly de facto, in contrast to de jure alliances.

Our theory linking regime type to coalition size begins with the type of war aims that different regimes are likely to pursue. Almost by definition, democratic leaders are accountable to larger

\footnotetext{
9 Although see more recent work by Mackie (2003).

10 See, for example, early theoretical work (Morgenthau 1978; Waltz 1979; Walt 1987), and examples of more recent work on institutional decision making related to designing, joining, and complying with alliances (Altfeld 1984; Morrow 1991; Siverson and Emmons 1991; Smith 1995; Simon and Gartzke 1996; Lai and Reiter 2000; Leeds 2003; Weitsman 2004; Tago 2005; Leeds, Mattes and Vogel 2009; Tago 2009; Kimball 2010; Cranmer, Desmarais and Kirkland 2012; Crescenzi et al. 2012; Mattes 2012; Benson, Bentley and Ray 2013; Gartzke and Weisiger 2013; Ikeda and Tago 2014; Tago and Ikeda 2015). For earlier measurement efforts see Russett (1971) and Singer and Small (1966), as well as later work by Gibler and Sarkees (2004) and Leeds et al. (2002).
} 
domestic constituencies than are autocracies, and so must provide benefits to a much larger number of people or groups in order to remain in power. For the same reasons that democratic leaders should logically focus on public goods spending internally in attempting to stay in office, and that autocrats should rely disproportionately on private goods spending (Lake 1992; Bueno de Mesquita et al. 1999; Bueno de Mesquita et al. 2003), non-democracies should seek out private benefits through their foreign policies, including the use of force, while democracies must generally prefer public foreign policy objectives. The basic "selectorate" logic developed to explain differences between the domestic policy preferences of leaders in democracies and autocracies applies equally to foreign policy decision making. Democratic leaders still value the acquisition of private goods through conquest, but large selectorates are less easily appeased through the distribution of private plunder. Democracies must be more easily led to war in pursuit of public goods, such as security or stable access to important economic resources or markets. Autocratic states in contrast should be more disposed to initiate or join contests with a focus on private goods.

At its core, our expectation that democracies tend to fight alongside larger sets of coalition partners rests on the expectation that democracies have a tendency to pursue war aims for which the incentive is to maximize coalition size, whereas non-democracies are more likely to seek war aims that produce incentives to fight alongside the minimum number of partners necessary to ensure victory. This expectation is, in turn, derived from expectations about the type of goods over which democracies and autocracies are most disposed to fight.

A state fighting for a private good-for example, control of territory or resources-receives the same probability-of-victory benefit from additional allies obtained by states fighting for social goods. However, states considering the option of merging military enterprises must also consider how to allocate the fruits of victory. The larger the number of partners involved in achieving victory, the smaller the portions of territory or plunder available for each participant. States may rationally be willing to accept a marginally higher risk of failure in exchange for a larger share of the spoils. Conversely, when a state is fighting with a goal that is non-rival, such as enforcing the territorial integrity norm (Zacher 2001; Fazal 2007), then there are few disincentives to recruiting many partners (Conybeare 1992; Conybeare 1994). States fighting for non-rival objectives should seek, and more often obtain, a larger number of partners than states that are fighting primarily to obtain private benefits. While combatants pursuing non-rival objectives can face free-rider problems in building coalitions (perhaps requiring the leadership of a major power), a country fighting for private goods is confronted by major positive costs for forming a coalition.

Conveniently, this logic applies both to targets and joiners as well as to war initiators. For example, the norm that state borders should not be changed by military force serves to enhance the security of all states in the system; therefore, the enforcement of this norm can usefully be viewed as a non-rival good. Defending states that limit their war aims to fending off the attacker and restoring the status quo have incentives to maximize coalition size (and democratic states have incentives to come to their aid to preserve a norm they value). Conversely, a state that is attacked may aim, in addition to defending the territory it currently holds, to turn the tables and seize territory from its attacker. Such a defender would face incentives to limit coalition size to avoid diluting the spoils of victory. These more expansive aims focused on securing rival goods are more likely among autocratic targets.

Our logic also holds for joiners. If a state is considering joining a coalition that is pursuing a rival good, a larger existing coalition means a smaller share of the spoils to any additional joiners. Thus, a state that is considering joining a coalition to seek rival goods has an incentive to avoid joining oversize coalitions - it is often better to join a small coalition with some probability of losing, but a large potential payoffs rather than joining a much larger coalition with a high probability of winning but diluted payoffs. When considering joining a coalition in pursuit of a non-rival good, however, such incentives to not exist, leading democracies, on average, to join larger coalitions. 
Democratic states, as they have less interest in the conquest of private (rival) goods, should do more of their fighting to defend norms and secure other global public goods. Consistent with this expectation, Sullivan and Gartner (2006) demonstrate empirically that democratic states are less likely to grant concessions when the belligerent state's war objectives include a change in the status quo, especially a demand for a revision of the territorial status quo or a change in regime. Similarly, democracies tend to unite against demands by revisionist states (Lake 1992). ${ }^{11}$

In addition to the main rationale detailed above, we can provide at least two other arguments linking democracy and coalition size. First, democracies may have stronger incentives than non-democracies to diffuse the costs of costly contests. Coalitions diversify risk, lowering war costs and reducing the variance in those costs. This is important because democratic states may face incentives to adopt minimax strategies when it comes to war costs. For example, Russett, argues that "governments lose popularity in proportion to the war's cost in blood and money" $(1990,46)$ and Gartzke notes that "war contrasts with citizens' interests in survival so that citizens have incentives to use their political influence to attempt to avert casualty-causing contests" $(2001,481) .{ }^{12}$ Filson and Werner (2004) demonstrate formally that democracies should be more likely than non-democracies to make concessions in order to avoid incurring war costs. By recruiting coalition partners, democratic states spread war costs across coalition members and placate domestic populations sensitive to the costs of war (Gartzke 2001; Koch and Gartner 2005).

Second, the participation of coalition partners may increase the legitimacy of a side or faction in a war. Heightened legitimacy may lower the costs of fighting by lowering the resistance to fighting by both domestic and international audiences (Weitsman 2004; Tago 2005; Ikeda and Tago 2014; Tago and Ikeda 2015), and it may also increase the probability of participation by additional democratic partners. Research on international institutions finds tangible evidence that support for the use of force from the international community makes it easier for a democratic leader to obtain domestic approval (Martin and Simmons 1998; Hurd 1999; Voeten 2005; Chapman 2007). Fighting alongside coalition partners may have a similar effect to receiving support from the international community. Constituents who see the conflict as legitimate are more likely to assist in the war effort. Opponents may also find it harder to resist the moral suasion of a coalition.

Each of the explanations above provides a plausible account of why the relative success of democracies in war may be tied to external relationships, rather than, or in addition to, innate war fighting advantages localized within liberal regimes. While we find our main argument logically more compelling, empirical adjudication among alternative accounts falls outside the scope of this paper. The arguments above all anticipate an indirect causal relationship between democracy and military victory, one in which coalition size or capability plays a critical intervening role. The remaining focus of this paper involves testing the general relationship between regime type, coalition size, or capability, and victory.

\section{TESTABLE IMPLICATIONS}

If the conventional wisdom in international relations is that democracy leads to an increased likelihood of victory (solid line in Figure 1), our perspective suggests that democracy more vigorously influences coalition size (dashed line), and that coalition size then affects whether states win wars or disputes (dotted line).

\footnotetext{
11 This logic is consistent with recent empirical findings from Wright and Diehl (2014) who find that "The willingness of democracies to engage and stand firm in territorial disputes should be greatest when the territory involved is regarded as a public good" (21). For more, see Wright (2014).

12 However, Gartzke (2001) finds that democracies do not protect citizens disproportionately by substituting capital for labor in military force structures, once development is taken into account.
} 
The relative impact of these direct and indirect effects of regime type and coalition size cannot be derived through logic, but must be estimated empirically. We can use the intervening variable argument made above to offer predictions. First, democracies should have more coalition partners when they experience militarized conflict and, given their higher numbers, these sets of coalition partners are likely to be cumulatively more powerful than those fighting alongside non-democracies.

HYPOTHESIS 1: Democracies experiencing disputes/wars tend to fight alongside more coalition partners than non-democracies experiencing disputes/wars.

HYPOTHESIS 1A: Democracies experiencing disputes/wars tend to fight alongside sets of coalition partners that are cumulatively more powerful than sets of coalition partners fighting alongside non-democracies experiencing disputes/wars.

Second, our claim of an indirect link between democracy and victory suggests that democracies tend to win their disputes and wars because they have more coalition partners. A test of the motivating puzzle of democratic victory requires that we establish not only that democracies in wars and disputes have more coalition partners, but also that states fighting with more partners tend to be victorious.

HYPOTHESIS 2: States that fight alongside a greater number of coalition partners tend to win the disputes/wars in which they are engaged.

HYPOTHESIS 2A: States that fight alongside more powerful sets of coalition partners tend to win the disputes/wars in which they are engaged.

Hypotheses 1 and 2 delineate the broad outlines of our argument. However, while necessary, each component is not sufficient separately to establish our claim that coalition size accounts for democratic victory. To do this, we need to assess a third set of hypotheses combining attributes of both of the other two hypotheses.

HYPOTHESIS 3: Democracies tend to win disputes/wars if and when they fight alongside a larger number of coalition partners.

HYPOTHESIS 3A: Democracies tend to win disputes/wars if and when they fight alongside more powerful sets of coalition partners.

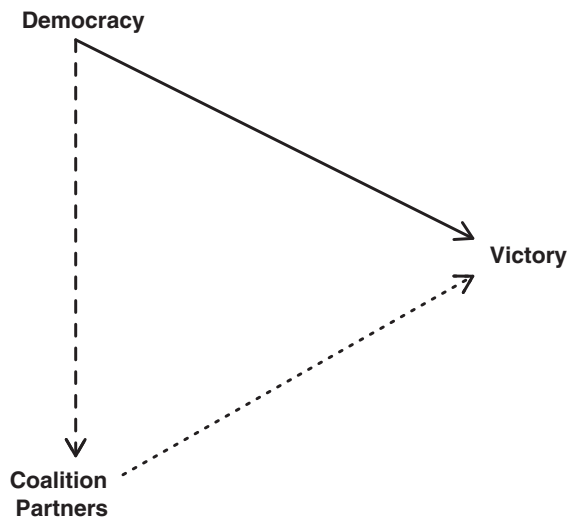

Fig. 1. Direct and indirect relationships between democracy and military victory 
EMPIRICAL ANALYSIS

\section{Dependent Variables and Sample}

For data on interstate conflict, we examine militarized interstate disputes (MIDs) involving displays or uses of force (levels 3-5) from 1816-2000, drawn from the dyadic MID (DYMID) data set (Maoz 2005). We include high-intensity, non-fatal MIDs as well as disputes with actual fighting because if large coalitions are effective in producing victory in fighting, they should also be effective in inducing opponents to back down before fighting. We omit the lowest intensity MIDs because these often result from accidents and other processes that do not directly reflect leader decision making (and thus are unrelated to the arguments posed above). The coding of minor fishing disputes, for example, might overrepresent democratic disputes (Weeks and Cohen 2007). To parallel existing studies, in some of the regressions below we limit the sample to wars only (i.e., disputes in which there are at least 1000 fatalities).

The dispute-participant is used as the unit of analysis, which means that one observation per participant in each dispute enters each statistical regression model. Errors are clustered on the dispute-side, a unique identifier that captures both the dispute number and whether the state in question is on side 1 or side 2 in the data.

The first dependent variable is number of partners, or the number of coalition partners on a given state's side. In some models, we also use an alternative binary version of this variable that is measured as 1 if the state side has more than two partners and 0 otherwise. We label this dichotomous variable as simply coalition. In hypotheses 1a, 2a, and $3 \mathrm{a}$, we operationalize coalition size differently, using the summed military capabilities of a state's partners as a measure of coalition size (partners' Composite Indicators of National Capabilities (CINC) score). Lastly, in the section 10.5 of the online appendix, we show that our results are also robust to measuring coalition size as the logged number of states on side $1 .^{13}$ As noted above, we take an inclusive view of what it means to be a partner-we consider any two states fighting on the same side of a conflict to be partners.

The second dependent variable, victory, is an ordinal variable that measures dispute outcome. The victory variable takes a value of 2 if side 1 achieves military victory or if side 2 concedes; it takes a value of 0 if side 2 achieves a military victory or side 1 concedes. Stalemates and compromises are assigned a value of $1 .{ }^{14}$ There is one observation per dispute-side, and side 1 always refers to the side in question - side 1 and side 2 are thus different than the originally defined sideA and sideB in the Maoz MID data set. We also use an alternative binary version of this variable (win) in which stalemates and compromises are coded as 0 (i.e., not victory).

\section{Other Data}

We use the Polity IV democracy score to measure regime type, which captures rich variation in the level of democracy (see Marshall, Jaggers and Gurr 2003; Marshall and Jaggers 2007). More variation should translate into a strong estimated effect for regime type on victory if such an independent effect indeed exists. However, because our theory focuses on the distinction between democracies and autocracies, we also use the Boix, Miller and Rosato (2013) binary measure of democracy.

\footnotetext{
${ }^{13}$ Because CINC scores already represent the share of total global capabilities, we do not log this variable in our primary specifications. However, our results are also robust to logging CINC scores (see section 10.5 in the appendix).

${ }^{14}$ We code "Released" as missing, as we do not know which side held the material/personnel in question. Similarly, we also code "Unknown" and "Joined ongoing war" as missing.
} 
The material capabilities of a given country, CINC score, and the summed capabilities of all of the states on side 2 of the conflict, opponent(s)' CINC score, are measured using the CINC data from the Correlates of War data set. CINC scores are composed of a state's share of the total population, urban population, consumption of energy, iron and steel production, number of military personnel, and military expenditures in the system. Following Reiter and Stam (2002), we include a measure of troop quality in some regressions. ${ }^{15}$

Finally, states may vary in their dispute propensity in ways that impact their interest in forming coalitions. States that are, ex ante very likely or very unlikely to go to war may tend to fight in different size coalitions when they do fight, and may face different probabilities of winning. ${ }^{16}$ Therefore, we control for the propensity of a given dyad to engage in a MID (levels 3-5). ${ }^{17}$ This dispute propensity control variable is then included in our directeddyad and dyad-level analyses discussed in the next section. ${ }^{18}$

In the following sections, we present results for Hypotheses 1-3, which make predictions regarding the number of coalition partners and Hypotheses 1a-3a, which make about the aggregate capabilities of coalition partners. In the online appendix, we demonstrate the robustness of these results to a variety of alternative specifications. The appendix includes analysis using a third measure of coalition size (the logged number of coalition partners in section 10.1 of the online appendix), and well as bivariate ordered probit results (an alternative to the bivariate probit models presented in the body of the paper in section 10.2 of the online appendix). We also conduct as extended comparison of our results with predictions from the literature on democratic alliance quality (e.g., Choi 2004), which is supplemented with additional empirical analyses (see sections 10.3 and 10.4 of the online appendix). In section 10.6, we conduct a temporal sensitivity analysis and a consider the system wide level of democracy. In section 10.7, we consider initiation and its interaction with regime type. In section 10.8, we demonstrate that our results are robust to a brand new data set for wars from 1816 to 2007 developed by Reiter, Stam and Horowitz (2014). Finally, we use permutation tests to show that our primary results are not artifacts of chance in section 10.9 (e.g., Gordon 2005). And in section 10.10, we evaluate the out of sample performance of the models using cross validation tests (e.g., Efron 1983; Ward, Greenhill and Bakke 2010; Hill and Jones 2014; Crabtree and Fariss 2015). We also estimate several of our models with different samples and reduced specifications (sections 10.12-10.13).

\section{More Democratic States Fight in Larger Coalitions}

Our first hypothesis is simply that democratic states fight alongside more partners. In tests of this hypothesis, the unit of analysis is the dispute-participant. Therefore, there can be multiple observations for each dispute in the MIDs data set.

\footnotetext{
${ }^{15}$ National military spending per soldier, divided by annual world average spending per soldier.

16 Some states may simply engage in more conflicts than others, which could lead to or influence the relationships we observe between the dispute outcomes, coalition size, and regime type. Specifically, the information that emerges from the historical interactions between states may be used by those states when forming coalitions in the first place (Crescenzi and Enterline 2001).

17 MID propensity scores are constructed using logistic regression to estimate annual MID probabilities for all directed dyads as a function of the time since the last DYMID. Time since last MID is modeled as a count variable with three natural cubic splines (Beck, Katz and Tucker 1998).

18 Statistical analyses were conducted using Stata 11.0. (2010). Additional analyses, including permutation tests and cross validation tests, and figures were generated in $R$ (R Development Core Team 2014). Permutation tests and cross validation tests are located in sections 10.9 and 10.10 of the online appendix.
} 

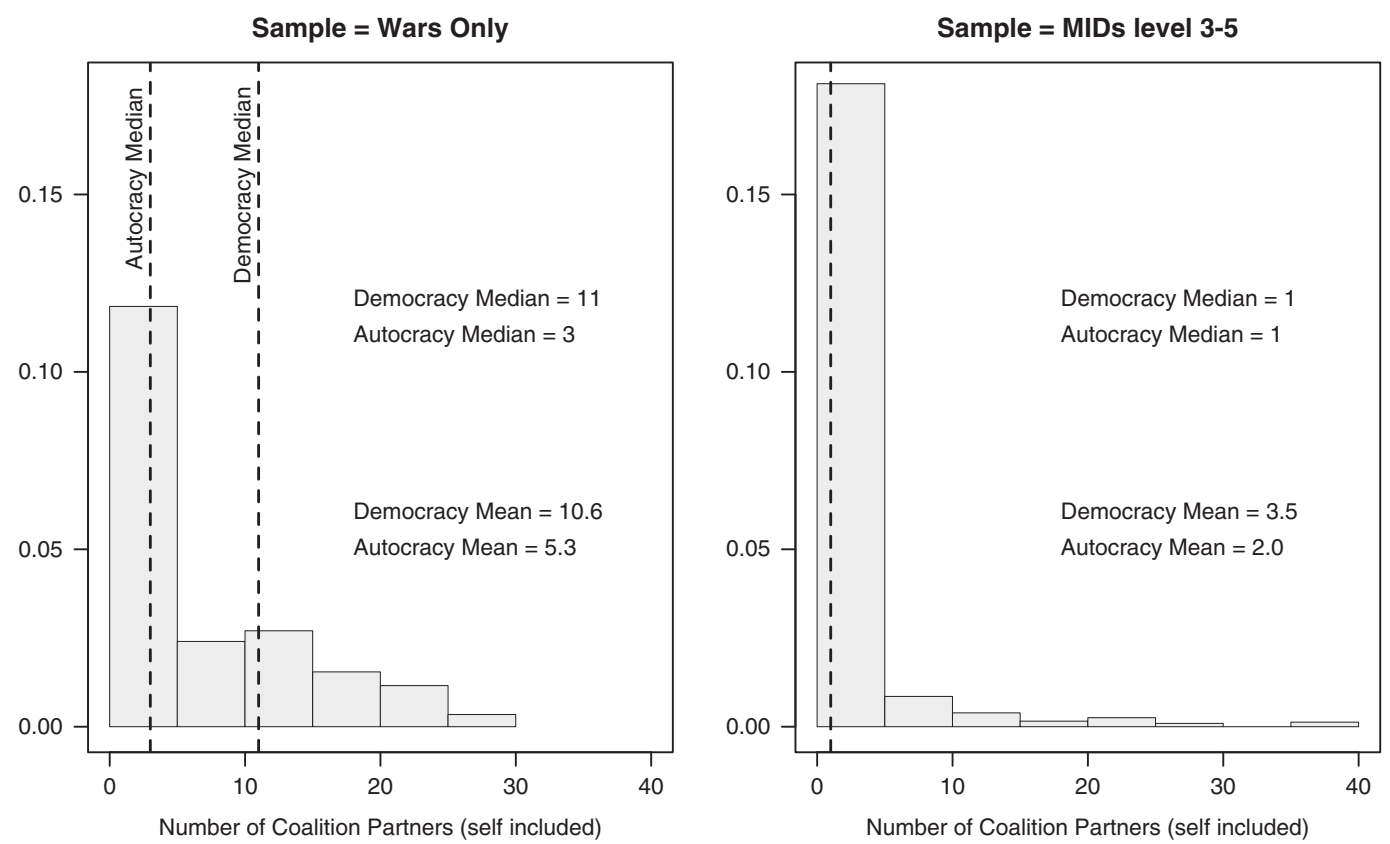

Fig. 2. Distribution of the number of partners in the sample of all war participants (left panel) and all militarized interstate dispute (MID) participants (right panel), 1816-2000

Note: the dashed line represent the median number of coalition partners in each panel.

TABLE $1 \quad$ Number of Coalition Partners

\begin{tabular}{|c|c|c|c|c|}
\hline & Wars Only & Wars Only & MIDs (3-5) & MIDs (3-5) \\
\hline Democracy (Polity IV) & $\begin{array}{l}0.039 \text { *** } \\
(0.010)\end{array}$ & & $\begin{array}{l}0.060^{* * * *} \\
(0.015)\end{array}$ & \\
\hline Democracy (Boix, Miller and Rosato) & & $\begin{array}{l}0.82 * * * \\
(0.15)\end{array}$ & & $\begin{array}{l}1.08 * * * \\
(0.22)\end{array}$ \\
\hline CINC score & $\begin{array}{c}1.13 \\
(1.06)\end{array}$ & $\begin{array}{c}0.54 \\
(1.03)\end{array}$ & $\begin{array}{c}-1.45 \\
(1.21)\end{array}$ & $\begin{array}{c}-1.48 \\
(1.14)\end{array}$ \\
\hline Opponent(s)' CINC score & $\begin{array}{c}0.70 \\
(1.28)\end{array}$ & $\begin{array}{c}0.96 \\
(1.20)\end{array}$ & $\begin{array}{c}2.08 \\
(1.46)\end{array}$ & $\begin{array}{c}2.35 \\
(1.46)\end{array}$ \\
\hline Constant & $\begin{array}{l}1.57 * * * \\
(0.25)\end{array}$ & $\begin{array}{l}1.27 * * * \\
(0.22)\end{array}$ & $\begin{array}{c}0.21 \\
(0.29)\end{array}$ & $\begin{array}{c}-0.22 \\
(0.24)\end{array}$ \\
\hline$\alpha$ constant & $\begin{array}{l}0.51 * * \\
(0.21)\end{array}$ & $\begin{array}{l}0.50 * * \\
(0.22)\end{array}$ & $\begin{array}{l}2.10 * * * \\
(0.099)\end{array}$ & $\begin{array}{l}2.10 * * * \\
(0.096)\end{array}$ \\
\hline Observations & 397 & 410 & 5019 & 5229 \\
\hline
\end{tabular}

Note: standard errors in parentheses. Specification: negative binomial regression with errors clustered on dispute-side. MIDs = militarized interstate disputes; $\mathrm{CINC}=$ Composite Indicators of National Capabilities.

$* \mathrm{p}<0.10, * * \mathrm{p}<0.05, * * * \mathrm{p}<0.01$

We use a negative binomial regression to evaluate the relationship between regime type and the number of partners. Many states fight without partners, leading to a high proportion of 0s in the dependent variable. We follow King (1989) in choosing the negative binomial model over Poisson regression, which assumes that the mean number of partners equals the variance in the number of partners. 

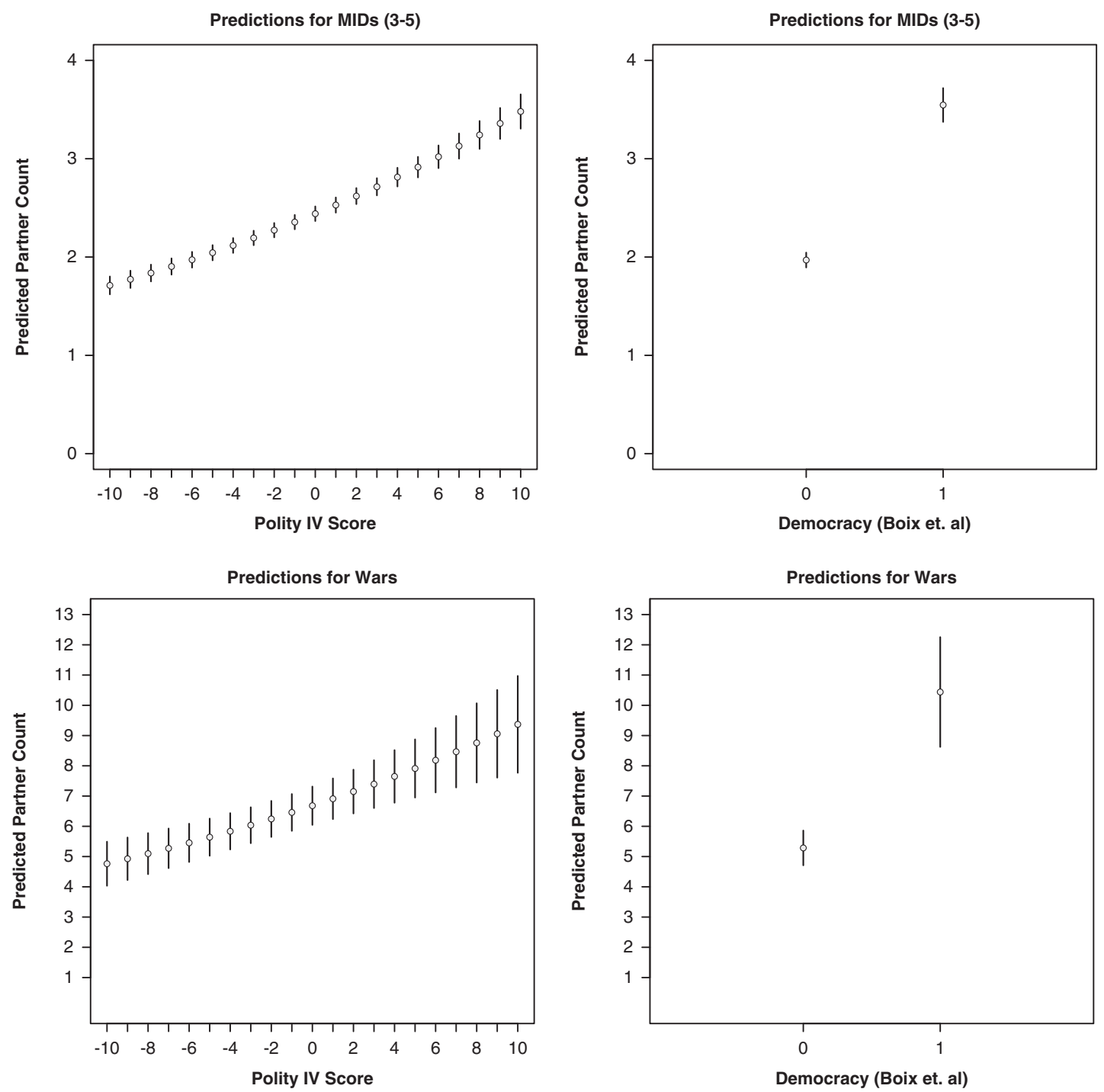

Fig. 3. Predicted number of partners as a function of two different measures of democracy for militarized interstate disputes (MIDs) (3-5) and wars only

Note: all other variables from the models are held at their mean values.

Figure 2 reports the distribution of the number of coalition partners for war participants and participants in major MIDs, 1816-2000. The mean number of partners for autocracies and for democracies appear as dashed vertical lines in each plot. ${ }^{19}$

Table 1 presents the results of this estimation in both the sample of all wars 1816-2000 and in the sample of MIDs (levels 3-5) during the same time period. Errors are clustered on dispute-side, which, as mentioned, captures both the dispute number and whether the state in question is on side 1 or side 2 . It is necessary to control for the material capabilities of the state in question (CINC score) because democracies are often stronger than their non-democratic counterparts (see Przeworski and Limongi 1997; Epstein et al. 2006), and because more capable

\footnotetext{
${ }^{19}$ For war participants, 76 percent of democracies and 71 percent of autocracies have at least one partner; for major MID participants, only 31 percent of democracies and 24 percent of autocracies have one or more partners.
} 
TABLE 2 Probability of Victory

\begin{tabular}{|c|c|c|c|c|}
\hline & (1) & (2) & (3) & (4) \\
\hline & Wars Only & Wars Only & MIDs (3-5) & MIDs (3-5) \\
\hline Number of partners & $\begin{array}{l}0.038 * * \\
(0.017)\end{array}$ & $\begin{array}{l}0.036 * * \\
(0.017)\end{array}$ & $\begin{array}{l}0.067 * * * \\
(0.013)\end{array}$ & $\begin{array}{l}0.067 * * * \\
(0.013)\end{array}$ \\
\hline Democracy (Polity IV) & $\begin{array}{c}0.021 \\
(0.015)\end{array}$ & & $\begin{array}{l}0.010^{* * * *} \\
(0.0038)\end{array}$ & \\
\hline Democracy (Boix, Miller and Rosato) & & $\begin{array}{l}0.48 * * \\
(0.23)\end{array}$ & & $\begin{array}{l}0.18 * * * \\
(0.058)\end{array}$ \\
\hline CINC score & $\begin{array}{l}5.09 * * * \\
(1.68)\end{array}$ & $\begin{array}{l}4.78^{* * * *} \\
(1.57)\end{array}$ & $\begin{array}{l}2.32 * * * \\
(0.46)\end{array}$ & $\begin{array}{l}2.37 * * * \\
(0.45)\end{array}$ \\
\hline Opponent(s)' CINC score & $\begin{array}{l}-2.95^{* * * *} \\
(0.83)\end{array}$ & $\begin{array}{c}-2.88^{* * * *} \\
(0.80)\end{array}$ & $\begin{array}{l}-2.44 * * * \\
(0.55)\end{array}$ & $\begin{array}{l}-2.44 * * * \\
(0.55)\end{array}$ \\
\hline Dyad MID propensity & $\begin{array}{l}-2.05 \\
(8.07)\end{array}$ & $\begin{array}{c}-1.69 \\
(8.06)\end{array}$ & $\begin{array}{r}-1.22 \\
(1.74)\end{array}$ & $\begin{array}{c}-0.96 \\
(1.74)\end{array}$ \\
\hline Troop quality & $\begin{array}{c}0.057 \\
(0.078)\end{array}$ & $\begin{array}{c}0.036 \\
(0.077)\end{array}$ & $\begin{array}{c}0.023 \\
(0.014)\end{array}$ & $\begin{array}{c}0.016 \\
(0.011)\end{array}$ \\
\hline Cut 1 & $\begin{array}{c}-0.36 \\
(0.31)\end{array}$ & $\begin{array}{c}-0.26 \\
(0.34)\end{array}$ & $\begin{array}{c}-1.24 * * * \\
(0.069)\end{array}$ & $\begin{array}{l}-1.17 * * * \\
(0.074)\end{array}$ \\
\hline Cut 2 & $\begin{array}{c}0.35 \\
(0.32)\end{array}$ & $\begin{array}{c}0.46 \\
(0.33)\end{array}$ & $\begin{array}{l}1.21 * * * \\
(0.063)\end{array}$ & $\begin{array}{l}1.27 * * * \\
(0.065)\end{array}$ \\
\hline Observations & 336 & 345 & 4104 & 4234 \\
\hline
\end{tabular}

Note: standard errors in parentheses. Specification: ordered probit with errors clustered on dispute-side. MIDs = militarized interstate disputes; $\mathrm{CINC}=$ Composite Indicators of National Capabilities. $* \mathrm{p}<0.10, * * \mathrm{p}<0.05, * * * \mathrm{p}<0.01$.

states may prove more attractive as potential security partners. We also control for the capabilities of the opposing state(s) (Opponent(s)' CINC score). For both measures of democracy in both samples, the level of democracy strongly predicts the number of coalition partners for states involved in disputes or wars. ${ }^{20}$

Figure 3 depicts the substantive effect of an increase in democracy on a state's expected number of partners in a dispute. This evidence supports the first link outlined by our argument: democratic states contest disputes in larger coalitions.

\section{More Partners, More Victory}

The second link of our argument (Hypothesis 2) posits that states that are accompanied by more partners are more likely to prevail in contests. To test this hypothesis, we estimate the probability of victory using ordered probit regression, where the dependent variable, victory, is equal to: loss (0), draw/stalemate (1), or win (2).

We control for regime type as well as the capabilities of the state in question (CINC score) and the enemy's summed material capabilities (Opponent(s)' CINC score). Including the state's own material capabilities as a regressor controls for the possibility that more powerful states may have an easier time recruiting partners. Including the material capabilities of a state's opponent(s) addresses any impact on the likelihood of victory attributable to the correlation between the number of partners on side 1 and the strength of side 2. Democracy controls for the direct effects of regime type on the probability of victory (i.e., effects not involving coalition size).

\footnotetext{
${ }^{20}$ An online appendix shows that these results also persist using a logged dependent variable.
} 

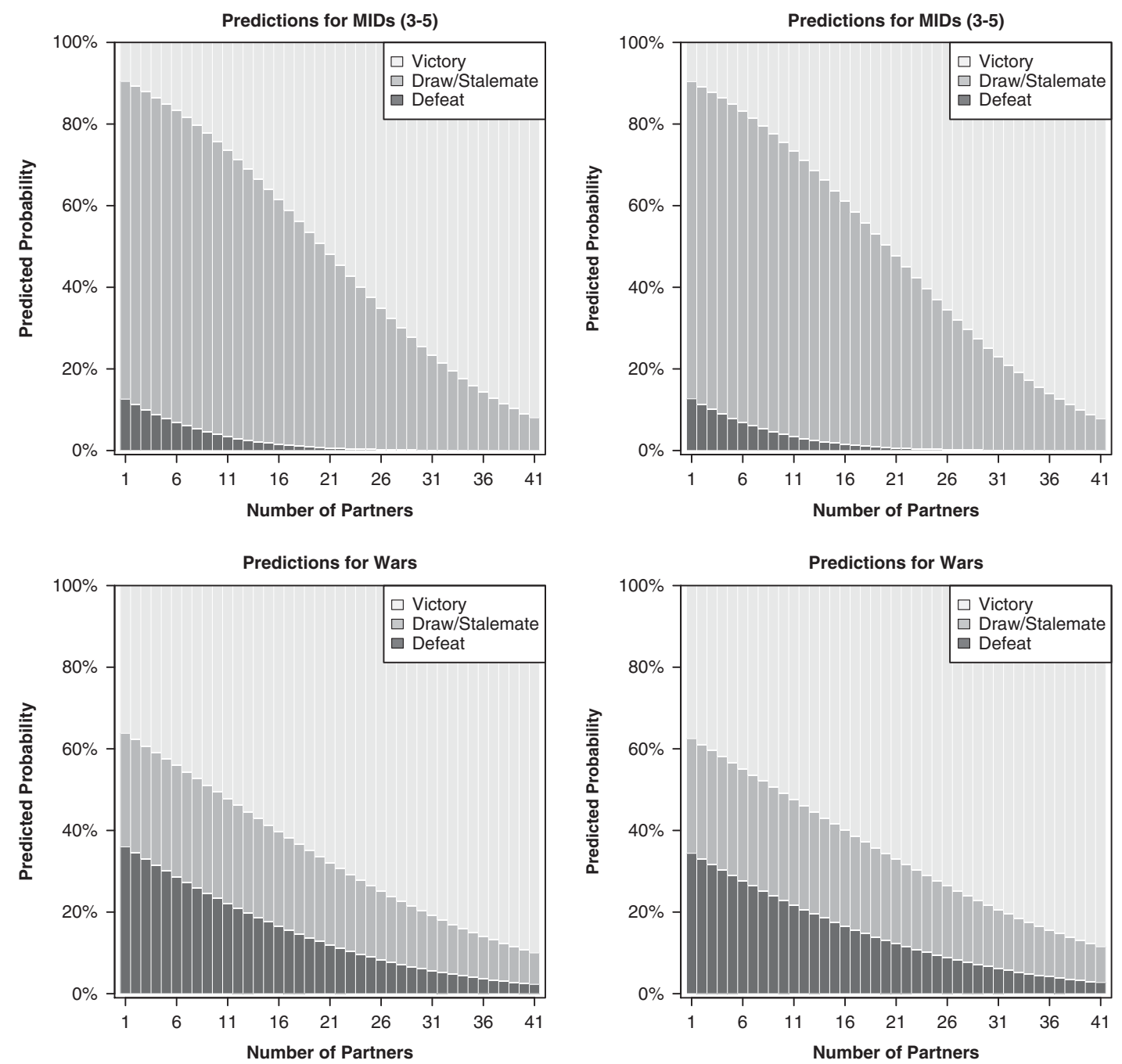

Fig. 4. Predicted probability of ordered outcomes during militarized interstate dispute (MIDs) (3-5) and wars only as a function of the number of coalition partners using two different measures of democracy (Polity IV in the two left panels and Boix, Miller and Rosato (2013) in the two right panels) Note: all other variables from the models are held at their mean or median values.

The results presented in Table 2 are consistent with Hypothesis 2. The number of coalition partners correlates positively and significantly with the likelihood of victory. Though not large, the effect is far from trivial. In wars, increasing the number of partners by $0.5 \mathrm{SD}$ (a 3 partner increase) is associated with an 11 percent increase in the probability of outright victory and an 10 percent decrease in the probability of outright defeat (both relative to draw/stalemate). ${ }^{21}$ For high-intensity MIDs, a 0.5 SD increase in the number of partners (a 2.6 partner increase) is associated with a 7 percent increase in the probability of outright victory and a 6 percent decrease in the probability of outright defeat. ${ }^{22}$

\footnotetext{
21 Based on Table 1, Model 1.

22 Based on Table 1, Model 3.
} 
TABLE $3 \quad$ Partners' Summed CINC Scores

\begin{tabular}{|c|c|c|c|c|}
\hline & Wars Only & Wars Only & MIDs (3-5) & MIDs (3-5) \\
\hline Democracy (Polity IV) & $\begin{array}{l}0.0080 * * * \\
(0.0022)\end{array}$ & & $\begin{array}{l}0.0015^{* * *} \\
(0.00045)\end{array}$ & \\
\hline Democracy (Boix, Miller and Rosato) & & $\begin{array}{l}0.15 * * * \\
(0.035)\end{array}$ & & $\begin{array}{l}0.024 * * * \\
(0.0075)\end{array}$ \\
\hline CINC score & $\begin{array}{c}0.044 \\
(0.17)\end{array}$ & $\begin{array}{l}0.0049 \\
(0.16)\end{array}$ & $\begin{array}{l}0.072 * * \\
(0.036)\end{array}$ & $\begin{array}{l}0.076 * * \\
(0.035)\end{array}$ \\
\hline Opponent(s)' CINC score & $\begin{array}{l}0.15 * * * \\
(0.053)\end{array}$ & $\begin{array}{l}0.15^{* * *} * \\
(0.048)\end{array}$ & $\begin{array}{l}0.088^{* * * *} \\
(0.033)\end{array}$ & $\begin{array}{l}0.088 * * \\
(0.034)\end{array}$ \\
\hline Constant & $\begin{array}{l}0.074 * * * \\
(0.020)\end{array}$ & $\begin{array}{c}0.024^{*} \\
(0.014)\end{array}$ & $\begin{array}{l}0.020 * * * \\
(0.0038)\end{array}$ & $\begin{array}{l}0.012 * * * \\
(0.0026)\end{array}$ \\
\hline $\begin{array}{l}\text { Observations } \\
R^{2}\end{array}$ & $\begin{array}{c}397 \\
0.175\end{array}$ & $\begin{array}{r}410 \\
0.233\end{array}$ & $\begin{array}{r}5019 \\
0.0363\end{array}$ & $\begin{array}{r}5229 \\
0.0356\end{array}$ \\
\hline
\end{tabular}

Note: standard errors in parentheses. Specification: ordinary least squares with errors clustered on dispute-side. MIDs $=$ militarized interstate disputes; $\mathrm{CINC}=$ Composite Indicators of National Capabilities.

$* \mathrm{p}<0.10, * * \mathrm{p}<0.05, * * * \mathrm{p}<0.01$.

Table 2 also reveals the expected results for the independent variables. More capable states tend to win, while states facing capable opponents tend to lose.

Figure 4 details the substantive effect of possessing partners on the predicted probability of winning a dispute. The evidence supports the second link of our causal argument; states with more partners are more likely to win disputes or wars.

\section{Aggregate Partner Capabilities}

In the preceding section, we measured the size of a state's coalition as the number of co-participants a state has in a conflict. A second way to measure coalition size is as the total power of a state's co-participants, which we measure as the summed CINC scores of all of the state's partners, partners' CINC score. Tables 3 and 4 recreate the results from Tables 1 and 2 with the use of this alternative measure. The results are consistent. More democratic states tend to fight with more powerful coalitions (Table 3; Figure 5), and states with more powerful sets of coalition partners are more likely to prevail (Table 4; Figure 6).

As with number of partners, more democratic states are more likely to fight in more capable coalitions. This result is robust to controlling for the power (CINC score) of the state in question, which is also positively correlated with the aggregate power of their coalition partners. More democratic states contest disputes alongside partners that are not only more numerous, but also cumulatively more powerful.

More powerful coalitions are also associated with a higher probability of victory. Consistent with Table 2, we also find that powerful states are more likely to prevail, while states facing more powerful opponents or coalitions are less likely to do so.

\section{Jointly Modeling Coalition Size and Victory}

While democracies fight alongside larger coalitions and states that fight alongside larger coalitions tend to win disputes and wars, we have not yet shown directly that democracies win wars because they fight alongside larger coalitions. Therefore, we next combine the two 
TABLE 4 Probability of Victory

\begin{tabular}{|c|c|c|c|c|}
\hline & (1) & (2) & (3) & (4) \\
\hline & Wars Only & Wars Only & MIDs (3-5) & MIDs (3-5) \\
\hline Partner(s)' CINC score & $\begin{array}{l}2.26^{* * *} \\
(1.14)\end{array}$ & $\begin{array}{l}1.91 * \\
(1.14)\end{array}$ & $\begin{array}{l}3.03 * * * \\
(0.73)\end{array}$ & $\begin{array}{l}3.01 * * * \\
(0.73)\end{array}$ \\
\hline Democracy (Polity IV) & $\begin{array}{c}0.0081 \\
(0.014)\end{array}$ & & $\begin{array}{l}0.011 * * * \\
(0.0039)\end{array}$ & \\
\hline Democracy (Boix, Miller and Rosato) & & $\begin{array}{c}0.31 \\
(0.23)\end{array}$ & & $\begin{array}{l}0.20 * * * \\
(0.059)\end{array}$ \\
\hline CINC score & $\begin{array}{l}5.13 * * * \\
(1.66)\end{array}$ & $\begin{array}{l}4.74 * * * \\
(1.55)\end{array}$ & $\begin{array}{l}1.80 * * * \\
(0.50)\end{array}$ & $\begin{array}{l}1.87 * * * \\
(0.49)\end{array}$ \\
\hline Opponent(s)' CINC score & $\begin{array}{c}-3.13 * * * \\
(0.82)\end{array}$ & $\begin{array}{c}-2.97 * * * \\
(0.79)\end{array}$ & $\begin{array}{c}-2.44 * * * \\
(0.55)\end{array}$ & $\begin{array}{c}-2.43^{* * * *} \\
(0.54)\end{array}$ \\
\hline Dyad MID propensity & $\begin{array}{c}0.62 \\
(7.85)\end{array}$ & $\begin{array}{c}0.73 \\
(7.82)\end{array}$ & $\begin{array}{r}-0.36 \\
(1.75)\end{array}$ & $\begin{array}{r}-0.12 \\
(1.73)\end{array}$ \\
\hline Troop quality & $\begin{array}{c}0.094 \\
(0.080)\end{array}$ & $\begin{array}{c}0.071 \\
(0.078)\end{array}$ & $\begin{array}{l}0.031 * * \\
(0.014)\end{array}$ & $\begin{array}{l}0.022 * * \\
(0.011)\end{array}$ \\
\hline Cut 1 & $\begin{array}{c}-0.29 \\
(0.31)\end{array}$ & $\begin{array}{c}-0.25 \\
(0.33)\end{array}$ & $\begin{array}{c}-1.23 * * * \\
(0.072)\end{array}$ & $\begin{array}{c}-1.16 * * * \\
(0.073)\end{array}$ \\
\hline Cut 2 & $\begin{array}{c}0.43 \\
(0.31)\end{array}$ & $\begin{array}{c}0.47 \\
(0.32)\end{array}$ & $\begin{array}{l}1.20 * * * \\
(0.072)\end{array}$ & $\begin{array}{l}1.27 * * * \\
(0.070)\end{array}$ \\
\hline Observations & 336 & 345 & 4104 & 4234 \\
\hline
\end{tabular}

Note: standard errors in parentheses. Specification: ordered probit with errors clustered on dispute-side. MIDs = militarized interstate disputes; CINC = Composite Indicators of National Capabilities. $* \mathrm{p}<0.10, * * \mathrm{p}<0.05, * * * \mathrm{p}<0.01$.

equations evaluated above into a bivariate probit regression. ${ }^{23}$ This approach allows us to estimate the joint relationship depicted in Figure 1.

The two equations in the bivariate probit model are estimated simultaneously. The relatedness of the two jointly estimated models is captured by a parameter for the correlation between the two outcomes as they are explained by the variables in the two models. Using this method, we can account for the direct relationship between war outcomes and coalition size, as well as the indirect relationship between regime type and the choice to enter a coalition, as captured in the first equation.

For these models, we collapse the count of the number of partners into the binary variable coalition, and we collapse the continuous measure of partners' strength into the binary variable powerful partners. The dependent variable for the second regression in each model is the binary variable win, in which stalemates and compromises are coded 0 (i.e., not winning). The same controls used above enter the two equations of this model and errors are clustered on disputeside. The original number of partners and Partners' CINC score variables enter the second equation. $^{24}$

Though we necessarily lose some information by creating binary variables out of the count and ordered dependent variables, we do gain computational tractability and numerical stability.

\footnotetext{
${ }^{23}$ Stata refers to this model as a "seemingly unrelated bivariate probit regression" because the two equations differ by at least one independent variable. A "bivariate probit regression" consists of two equations with the same independent variables. Our two equations differ by one variable.

24 There is no reason to collapse these variables when they enter the right side of the second equation. To do so would only destroy information contained in the variables.
} 

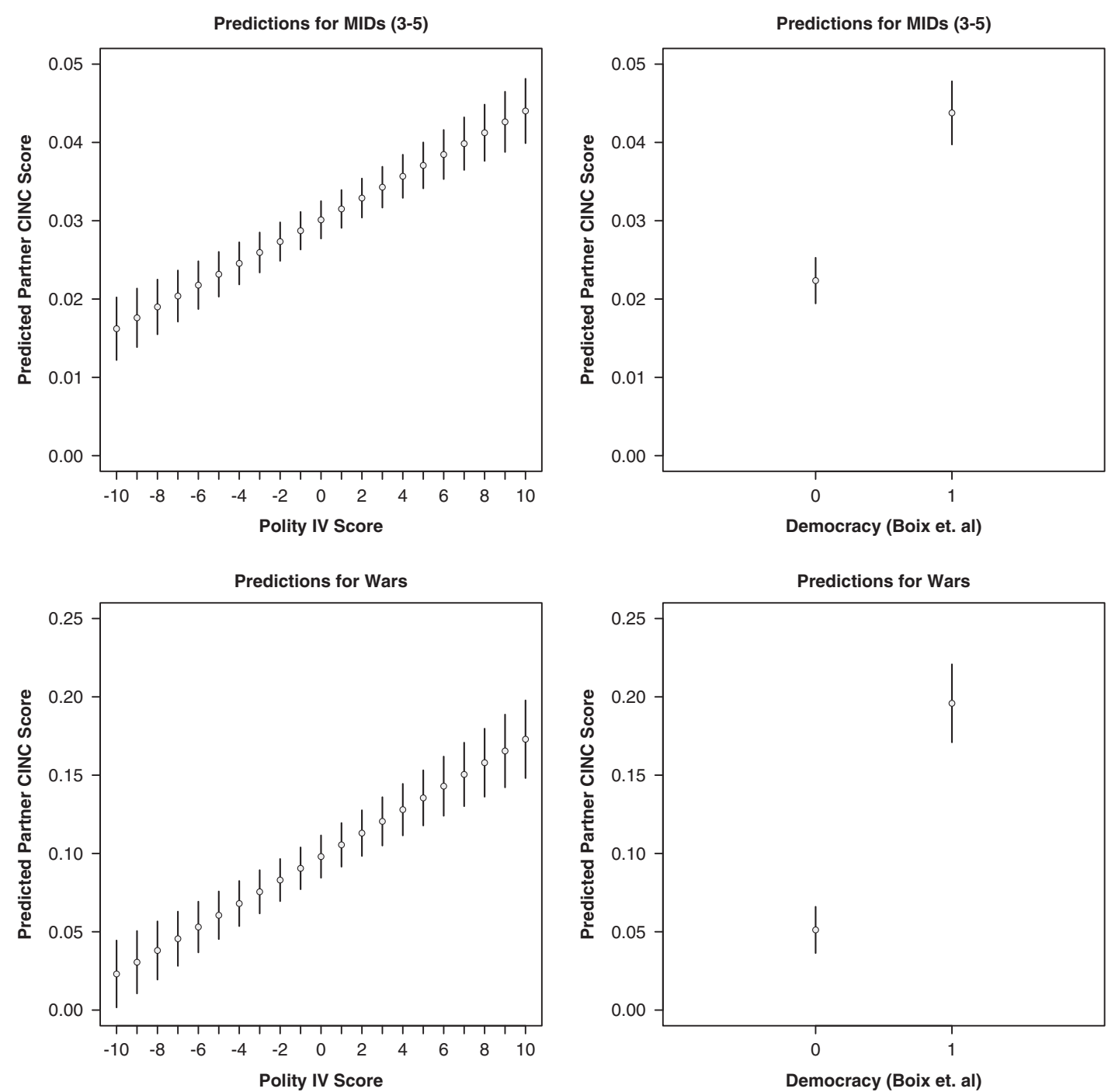

Fig. 5. Predicted Composite Indicators of National Capabilities (CINC) score for all coalitions partners as a function of two different measures of democracy for militarized interstate disputes (MIDs) (3-5) and wars only Note: all other variables from the models are held at their mean values.

As Cameron and Trivedi (2005) discuss, "[g]eneralizations to multivariate probit are obvious though will experience numerical challenges because of higher order integrals" (523). However, Cameron and Trivedi (2005) go on to state that when the outcome variables are "ordered then the model can be generalized to a bivariate ordered probit model" (523). We also estimate bivariate ordered probit models in the appendix and the results are generally consistent.

Tables 5 and 6 display results that corroborate the findings presented earlier and lend further support to both links in our argument. Democracies tend to win the wars that they fight, not because of a direct effect of regime type on victory, but because they fight as part of larger coalitions. Note that no statistically significant relationship exists between the probability of victory and level of democracy when the number of coalition partners or strength of coalition 

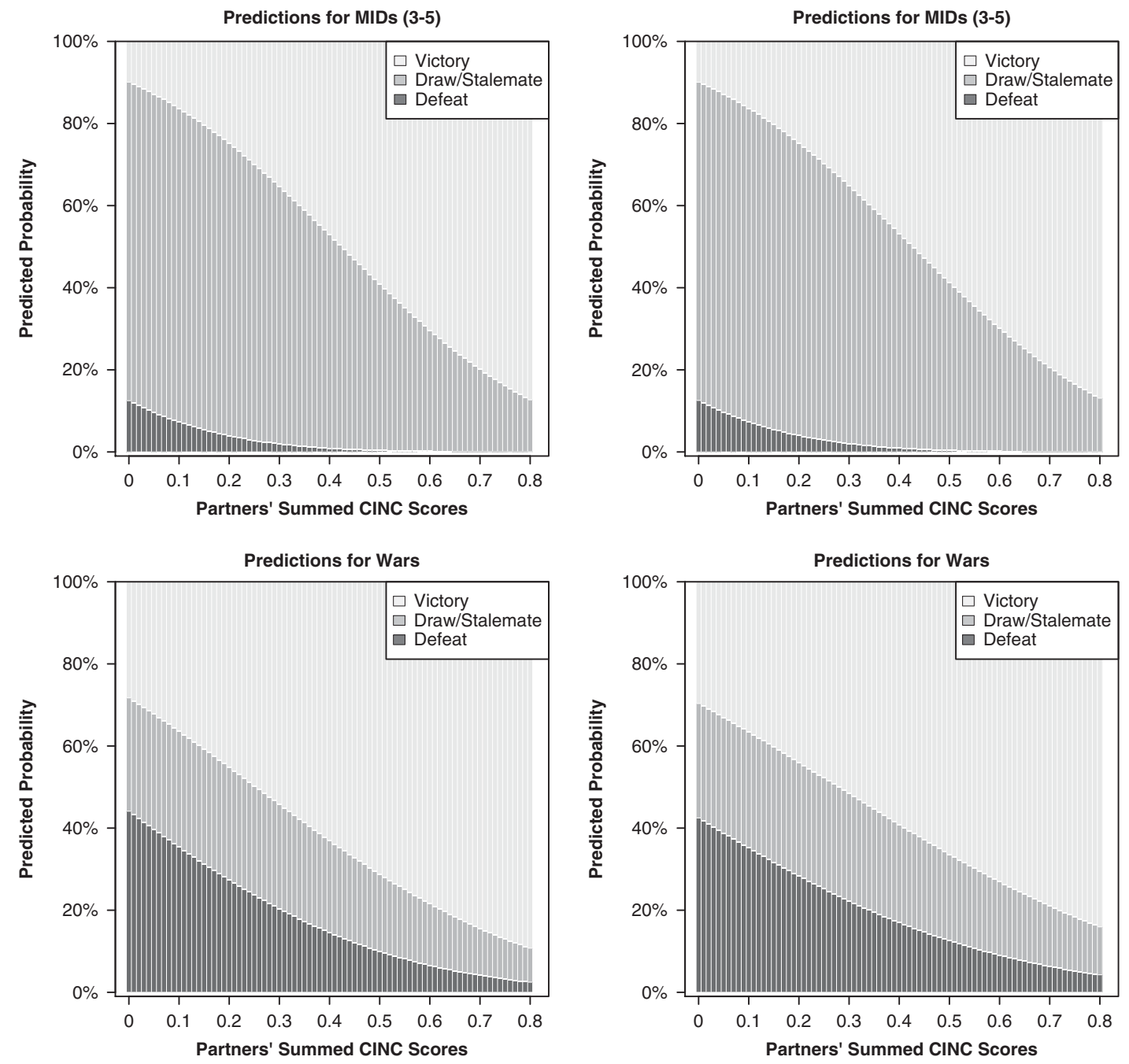

Fig. 6. Predicted probability of ordered outcomes during militarized interstate disputes (MIDs) (3-5) and wars only as a function of partners' summed Composite Indicators of National Capabilities (CINC) scores using two different measures of democracy (Polity IV in the two left panels and Boix, Miller and Rosato (2013) in the two right panels)

Note: all other variables from the models are held at their mean or median values.

partners is accounted for. Meanwhile, the number/strength of coalition partners variable is significant in each of the models in both tables. ${ }^{25}$

\section{Disaggregating the Data}

It is often helpful in analyzing regression results to disaggregate the data to show the strength of relationships across the full range of values. For example, it could be that democracies attract

\footnotetext{
25 Estimating the joint model in bivariate probit necessitates that we collapse the number of partners measure into a binary dependent variable. Table 5 reports results when the number of partners is greater than 2 and 0 otherwise. Table 6 reports when the summed CINC scores of coalition partners are $>0.1$. We explore the results across the full range of data in the next section.
} 
TABle $5 \quad$ Joint Probability of Partners and Victory: Bivariate Probit

\begin{tabular}{|c|c|c|c|c|}
\hline & (1) & (2) & (3) & (4) \\
\hline & Wars Only & Wars Only & MIDs (3-5) & MIDs (3-5) \\
\hline \multicolumn{5}{|l|}{$\mathrm{DV}=$ coalition } \\
\hline Democracy (Polity IV) & $\begin{array}{l}0.047 * * * \\
(0.017)\end{array}$ & & $\begin{array}{l}0.029 * * * \\
(0.0076)\end{array}$ & \\
\hline CINC score & $\begin{array}{c}-0.53 \\
(1.49)\end{array}$ & $\begin{array}{c}-0.61 \\
(1.44)\end{array}$ & $\begin{array}{c}-0.32 \\
(0.63)\end{array}$ & $\begin{array}{c}-0.24 \\
(0.62)\end{array}$ \\
\hline Opponent(s)' CINC score & $\begin{array}{c}1.54 \\
(1.01)\end{array}$ & $\begin{array}{c}1.48 \\
(1.02)\end{array}$ & $\begin{array}{l}2.01 * * * \\
(0.68)\end{array}$ & $\begin{array}{l}2.04 * * * \\
(0.68)\end{array}$ \\
\hline Dyad MID propensity & $\begin{array}{l}16.0 * \\
(9.51)\end{array}$ & $\begin{array}{l}16.6^{*} \\
(9.50)\end{array}$ & $\begin{array}{c}2.94 \\
(3.30)\end{array}$ & $\begin{array}{c}3.51 \\
(3.29)\end{array}$ \\
\hline Democracy (Boix, Miller and Rosato) & & $\begin{array}{l}0.68 * * * \\
(0.25)\end{array}$ & & $\begin{array}{l}0.45^{* * * *} \\
(0.11)\end{array}$ \\
\hline Constant & $\begin{array}{c}-0.48 \\
(0.35)\end{array}$ & $\begin{array}{c}-0.72^{* *} \\
(0.36)\end{array}$ & $\begin{array}{l}-1.38 * * * \\
(0.13)\end{array}$ & $\begin{array}{l}-1.57 * * * \\
(0.12)\end{array}$ \\
\hline \multicolumn{5}{|l|}{$\mathrm{DV}=$ win } \\
\hline Number of partners & $\begin{array}{c}0.046^{*} \\
(0.027)\end{array}$ & $\begin{array}{c}0.041 \\
(0.027)\end{array}$ & $\begin{array}{l}0.088^{* * *} \\
(0.018)\end{array}$ & $\begin{array}{l}0.088 * * * \\
(0.018)\end{array}$ \\
\hline Democracy (Polity IV) & $\begin{array}{c}0.012 \\
(0.023)\end{array}$ & & $\begin{array}{c}-0.00041 \\
(0.0058)\end{array}$ & \\
\hline Democracy (Boix, Miller and Rosato) & & $\begin{array}{c}0.28 \\
(0.35)\end{array}$ & & $\begin{array}{c}-0.069 \\
(0.089)\end{array}$ \\
\hline CINC score & $\begin{array}{l}5.18 * * * \\
(1.41)\end{array}$ & $\begin{array}{l}4.88 * * * \\
(1.31)\end{array}$ & $\begin{array}{l}3.30 * * * \\
(0.43)\end{array}$ & $\begin{array}{l}3.44 * * * \\
(0.40)\end{array}$ \\
\hline Opponent(s)' CINC score & $\begin{array}{l}-2.51 * * * \\
(0.95)\end{array}$ & $\begin{array}{c}-2.39 * * \\
(0.94)\end{array}$ & $\begin{array}{c}-0.099 \\
(0.54)\end{array}$ & $\begin{array}{c}-0.15 \\
(0.54)\end{array}$ \\
\hline Troop quality & $\begin{array}{c}0.094 \\
(0.090)\end{array}$ & $\begin{array}{c}0.085 \\
(0.087)\end{array}$ & $\begin{array}{c}0.032 * \\
(0.017)\end{array}$ & $\begin{array}{c}0.026 * \\
(0.013)\end{array}$ \\
\hline Dyad MID propensity & $\begin{array}{c}-4.29 \\
(9.21)\end{array}$ & $\begin{array}{c}-3.13 \\
(9.39)\end{array}$ & $\begin{array}{c}3.19 \\
(2.29)\end{array}$ & $\begin{array}{c}3.23 \\
(2.27)\end{array}$ \\
\hline Constant & $\begin{array}{c}-0.45 \\
(0.32)\end{array}$ & $\begin{array}{c}-0.53 \\
(0.33)\end{array}$ & $\begin{array}{c}-1.66 * * * \\
(0.082)\end{array}$ & $\begin{array}{c}-1.63 * * * \\
(0.084)\end{array}$ \\
\hline Arc-hyperbolic tangent & $\begin{array}{c}-0.17 \\
(0.28)\end{array}$ & $\begin{array}{c}-0.14 \\
(0.29)\end{array}$ & $\begin{array}{c}0.097 \\
(0.12)\end{array}$ & $\begin{array}{c}0.11 \\
(0.12)\end{array}$ \\
\hline Observations & 344 & 353 & 4534 & 4675 \\
\hline
\end{tabular}

Note: standard errors in parentheses.

MIDs $=$ militarized interstate disputes; $\mathrm{CINC}=$ Composite Indicators of National Capabilities . $* \mathrm{p}<0.10, * * \mathrm{p}<0.05, * * * \mathrm{p}<0.01$.

more coalition partners because they win. If democracies are more effective or charismatic coalition partners, then we again return to characteristics of regimes as an explanation for democratic victory. We want to confirm that the relationship between winning and coalition size is broadly consistent in all regions of the data. Figure 7 reports the probability of victory for 
TABLE $6 \quad$ Joint Probability of Allies and Victory

\begin{tabular}{|c|c|c|c|c|}
\hline & (1) & (2) & (3) & (4) \\
\hline & Wars Only & Wars Only & MIDs (3-5) & MIDs (3-5) \\
\hline \multicolumn{5}{|l|}{ DV = coalition $(\mathrm{CINC})$} \\
\hline Democracy (Polity IV) & $\begin{array}{l}0.11 * * * \\
(0.023)\end{array}$ & & $\begin{array}{l}0.042 * * * \\
(0.011)\end{array}$ & \\
\hline CINC score & $\begin{array}{c}-1.28 \\
(2.22)\end{array}$ & $\begin{array}{c}-1.53 \\
(2.15)\end{array}$ & $\begin{array}{c}0.76 \\
(0.89)\end{array}$ & $\begin{array}{c}0.93 \\
(0.86)\end{array}$ \\
\hline Opponent(s)' CINC score & $\begin{array}{c}0.75 \\
(0.96)\end{array}$ & $\begin{array}{c}0.99 \\
(0.98)\end{array}$ & $\begin{array}{c}1.01 \\
(0.67)\end{array}$ & $\begin{array}{c}1.04 \\
(0.66)\end{array}$ \\
\hline Dyad MID propensity & $\begin{array}{r}1.15 \\
(11.1)\end{array}$ & $\begin{array}{r}0.65 \\
(11.3)\end{array}$ & $\begin{array}{c}-0.18 \\
(4.86)\end{array}$ & $\begin{array}{c}-0.28 \\
(4.84)\end{array}$ \\
\hline Democracy (Boix, Miller and Rosato) & & $\begin{array}{l}1.69 * * * \\
(0.37)\end{array}$ & & $\begin{array}{l}0.56^{* * * *} \\
(0.16)\end{array}$ \\
\hline Constant & $\begin{array}{l}-1.50 * * * \\
(0.38)\end{array}$ & $\begin{array}{l}-2.12^{* * *} \\
(0.46)\end{array}$ & $\begin{array}{c}-2.17 * * * \\
(0.15)\end{array}$ & $\begin{array}{c}-2.35^{* * *} \\
(0.18)\end{array}$ \\
\hline \multicolumn{5}{|l|}{$\mathrm{DV}=$ win } \\
\hline Partner(s)' CINC score & $\begin{array}{l}3.96 \text { *** } \\
(1.33)\end{array}$ & $\begin{array}{l}3.86 * * * \\
(1.40)\end{array}$ & $\begin{array}{l}4.72 * * * \\
(0.80)\end{array}$ & $\begin{array}{l}4.77 * * * \\
(0.78)\end{array}$ \\
\hline Democracy (Polity IV) & $\begin{array}{c}-0.013 \\
(0.020)\end{array}$ & & $\begin{array}{c}0.0014 \\
(0.0057)\end{array}$ & \\
\hline CINC score & $\begin{array}{l}5.01 * * * \\
(1.31)\end{array}$ & $\begin{array}{l}4.71 * * * \\
(1.22)\end{array}$ & $\begin{array}{l}2.34 * * * \\
(0.54)\end{array}$ & $\begin{array}{l}2.51 * * * \\
(0.51)\end{array}$ \\
\hline Opponent(s)' CINC score & $\begin{array}{c}-2.93 * * * \\
(0.85)\end{array}$ & $\begin{array}{c}-2.77 * * * \\
(0.82)\end{array}$ & $\begin{array}{c}-0.19 \\
(0.55)\end{array}$ & $\begin{array}{c}-0.24 \\
(0.54)\end{array}$ \\
\hline Troop quality & $\begin{array}{c}0.10 \\
(0.072)\end{array}$ & $\begin{array}{c}0.088 \\
(0.069)\end{array}$ & $\begin{array}{l}0.046^{* * * *} \\
(0.017)\end{array}$ & $\begin{array}{l}0.035^{* * *} \\
(0.014)\end{array}$ \\
\hline Dyad MID propensity & $\begin{array}{c}-0.81 \\
(8.92)\end{array}$ & $\begin{array}{c}-0.23 \\
(8.86)\end{array}$ & $\begin{array}{l}4.77 * * \\
(2.41)\end{array}$ & $\begin{array}{l}4.77 * * \\
(2.35)\end{array}$ \\
\hline Democracy (Boix, Miller and Rosato) & & $\begin{array}{c}-0.16 \\
(0.36)\end{array}$ & & $\begin{array}{c}-0.018 \\
(0.084)\end{array}$ \\
\hline Constant & $\begin{array}{c}-0.59 * * \\
(0.30)\end{array}$ & $\begin{array}{c}-0.53 \\
(0.32)\end{array}$ & $\begin{array}{c}-1.66^{* * *} \\
(0.094)\end{array}$ & $\begin{array}{c}-1.64 * * * \\
(0.090)\end{array}$ \\
\hline Arc-hyperbolic tangent & $\begin{array}{c}-0.65 * * * \\
(0.24)\end{array}$ & $\begin{array}{c}-0.73 * * \\
(0.33)\end{array}$ & $\begin{array}{c}-0.15 \\
(0.16)\end{array}$ & $\begin{array}{c}-0.17 \\
(0.15)\end{array}$ \\
\hline Observations & 344 & 353 & 4534 & 4675 \\
\hline
\end{tabular}

Note: standard errors in parentheses. Specification: bivariate probit with errors clustered on dispute-side. MIDs = militarized interstate disputes; CINC = Composite Indicators of National Capabilities. $* \mathrm{p}<0.10, * * \mathrm{p}<0.05, * * * \mathrm{p}<0.01$.

democracies and autocracies for every possible number of coalition partners. The figure thus allows one to compare the probability of victory for democracies with two partners to the probability of victory for autocracies with two partners, and to compare democracies with autocracies again when they each have three partners, and so on. 


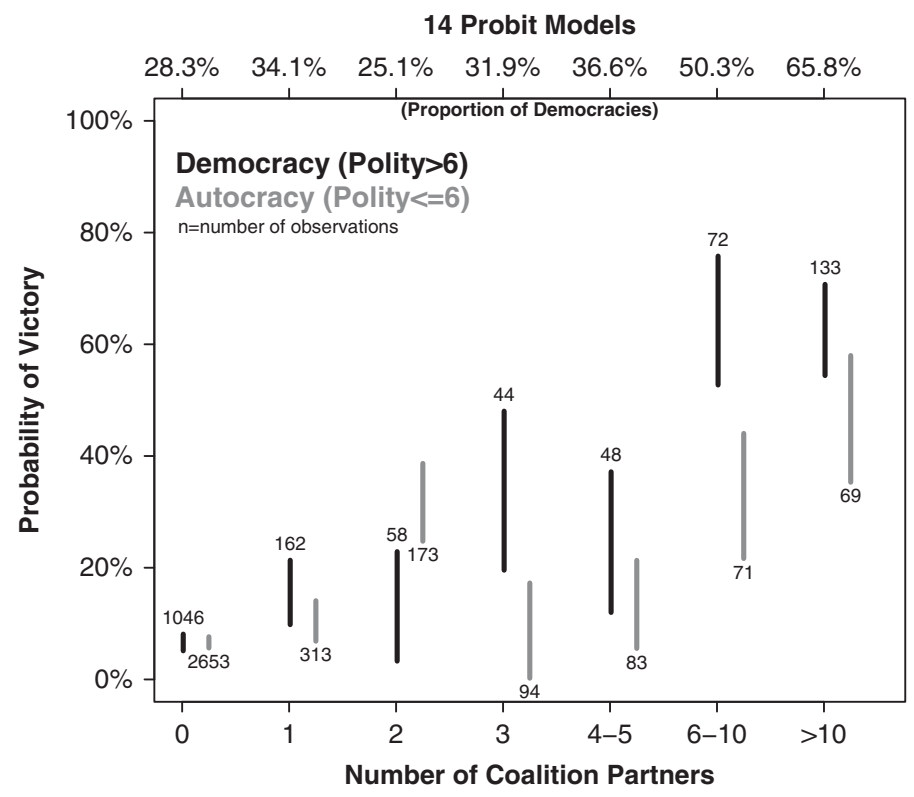

Fig. 7. The probability of victory by regime type, varying number of coalition partners

Evaluating the effects of regime type and coalition size at different thresholds is somewhat complex. Figure 7 helps to make sense of different combinations of democracy and coalition size by displaying the distributions for the probability of victory estimated from 14 probit regression models. Each regression is estimated on observations that are all of the same regime type and have the same number of coalition partners. Some observations were consolidated in order to estimate each model on at least 100 observations. For example, observations were included in the same model if they had 4 or 5 coalition partners. These models also include the controls as outlined previously. The percentages displayed along the top horizontal axis of the figure represent the proportion of democracies for each "bin" of partner counts. The number of observations in each model is displayed above the democracy probability distributions and under the autocracy probability distributions.

Disaggregation of the relationship between regime type and victory by number of coalition partners confirms the basic picture provided by the previous analysis. Democracies are not generally more likely to win wars and disputes independent of the count of partners. Fighting with more partners increases the probability of victory for both democracies and autocracies. The results also show that, for most values of coalition size, democracies have a higher probability of victory than autocracies, which is consistent with the small positive, but statistically insignificant, effect of democracy on victory reported in the bottom half of Table 5 . The effect of the number of coalition partners on victory is clearly much stronger than the effect of regime type. When fighting alone, a democracy is no more likely to win wars or disputes than an autocracy, while an autocracy fighting with more than six coalition partners is far more likely to achieve victory than an unssisted democracy.

Not only is a larger number of coalition partners associated with a higher probability of victory, but consistent with Hypothesis 1, more democratic participants fight with more partners. This is apparent in the proportion of democracies figures reported above each "bin" which generally increase with the size of the coalition. The ratio of democracies to 
non-democracies increases as we move from left to right on the chart, reflecting the fact that democracies tend to have more partners. ${ }^{26}$

Finally, Figure 7 also casts considerable doubt on the assertion that better democratic war fighting leads more states to partner with democracies. While democracies have more partners on average, many democracies possess no partners or few partners. A theory in which superior democratic war fighting leads democracies to attract more partners must, thus grapple with the fact that democracies vary to a considerable degree in their apparent attractiveness and therefore must vary in (perceived) battlefield effectiveness. One must either conclude that at least some democracies are less effective than some autocracies at war fighting, or that variation in coalition size is associated with other factors besides wartime effectiveness. We prefer to attribute the success of democracies to the fact that democracies have more coalition partners, as the evidence from Figure 7 is that fighting alongside more numerous partners unambiguously increases the probability of victory.

\section{A Comparison with Previous Findings}

It is useful to contrast our empirical approach with that taken by Reiter and Stam (Reiter and Stam 1998; Reiter and Stam 2002), who conducted the seminal work on democratic victory. Unlike Downes (2009), our intent is not to challenge their core findings: we agree that democracies tend to win the wars they fight. Thus, we structure our analysis to test our hypotheses, rather than to replicate their findings exactly. Most notably, because we wish to model both the direct effect of regime type on victory and its indirect effect (via coalition size), we adopt a bivariate modeling approach in our test of Hypotheses 3 and 3a.

Reiter and Stam $(2002,45)$ treat democracy as a continuous variable and predict a linear relationship between democracy and victory among target states and a non-linear relationship among war initiators. ${ }^{27}$ Our theory applies to initiators, joiners, and targets alike and addresses the distinction between democracies and autocracies rather than the effect (curvilinear or otherwise) of a continuous measure of democracy. Therefore, we employ both the continuous Polity measure and a binary measure of regime type and we do not interact regime type with initiation.

While we conduct our analysis on a sample of wars, we also expand our sample to include all high-intensity MIDs (there is nothing in our theory specific to conflicts with over 1000 battle deaths, the threshold for the wars only sample). ${ }^{28}$

Despite these differences in approach, Reiter and Stam's original findings are actually not in conflict with our argument: they find a large and robust effect of coalition size on victory and this effect is statistically stronger in their models than the direct effects of regime type. However, their model is not designed to capture the possibility that coalition size is, as we show, determined by regime type. ${ }^{29}$ Once we account for the indirect effect of democracy on

\footnotetext{
${ }^{26}$ We find consistent, statistically significant differences in proportion when comparing the proportion of democracies in the "high" number of partner bins with those in the "low" number of partner bins. Recall that Table 5 reports results when the number of partners is greater than 2 and 0 otherwise. The proportion of democracies in this high category is 48.20 percent and the low category is 28.76 percent. The difference in proportion for this cut-point is -19.45 percent $(\mathrm{p}<0.001)$.

27 They theorize that risk-acceptant mixed regimes are more likely to initiate unsuccessful conflicts.

28 We omit Reiter and Stam's controls for strategy and terrain, which are only available for a subset of conflicts. These variables should not confound the relationship between regime type and victory.

29 Reiter and Stam $(1998,387)$ find that the mean ally capabilities among democratic initiators are not significantly different than the mean ally capabilities of democratic defenders and autocracies-because their theory is specifically about initiation, they do not compare the average size of capabilities of alliances between democracies and autocracies overall.
} 
victory via coalition size, we no longer observe the strong direct effect of democracy that Reiter and Stam identify. ${ }^{30}$ Thus, while do not rule out the possibility that Reiter and Stam are correct and that, at the margins, democracies are superior war fighters, statistically these direct effects of regime type on victory pale in comparison with the indirect effect of regime type on victory through coalitions size.

\section{CONCLUSION}

The theory and results presented here provide a simple and intuitive link between regime type and war-fighting success: democracies win the wars they fight because they are joined in disputes and warfare by larger and more powerful coalitions. We show that democracies fight with more coalition partners than non-democracies, that states with more partners are more likely to prevail, and that the indirect effect of democracy on war-fighting success through coalition size subsumes the direct effect of regime type on victory. These results are robust to a wide range of alternative specifications, shown both here and in the online appendix, and the core relationships are consistent across the full range of the data. We also present theoretical and empirical reasons for favoring our "quantity" argument regarding democratic coalition over "quality" arguments made elsewhere.

Theoretically, we have linked the incentive to fight alongside additional partners with the differential domestic incentives faced by democratic and non-democratic political leaders. Specifically, each partner brings additional material capabilities to the war effort. Additional partners lower war costs, and also reduce the variance in war costs paid by each state. This reduction in war costs is a direct benefit to the citizens of each democracy paying for and participating in the conflict. Moreover, war over issues that democracies care about requires no significant division of the spoils, encouraging initial participants to maximize coalition size. In contrast, additional partners dilute the payoffs of conflicts over private goods, such as territory and tangible resources, which seem more often to motivate non-democracies to fight.

Definitive tests of the mechanism(s) linking regime type to coalition size require more precise data that are able to distinguish between war aims with primarily public goods components and war aims with primarily private goods components. Similarly, information about the costs born by publics in terms of both troop deployments and casualties in addition to the financial and material resources allocated by each state within a coalition would allow us to further test the causal mechanisms of our argument. Future research will attempt to provide more direct evidence regarding these mechanisms. However, the results presented here make a strong empirical case for our central assertion: democracies win the wars that they fight because they fight alongside more (and cumulatively more powerful) partners.

\section{REFERENCES}

Altfeld, Michael F. 1984. 'The Decision to Ally: A Theory and Test'. Western Political Quarterly 37(4):523-44.

Arrow, Kenneth J. 1951. Social Choice and Individual Values. New York, NY: John Wiley \& Sons.

Beck, Nathaniel, Jonathan N. Katz, and Richard Tucker. 1998. 'Taking Time Seriously: Time-Series-Cross-Section Analysis with a Binary Dependent Variable'. American Journal of Political Science 42(4):1260-88.

\footnotetext{
${ }^{30}$ We also control for the material capabilities of the opposing state or coalition, which Reiter and Stam do not do, keeping in mind that their theory involves conflict selection by democracies.
} 
Benson, Brett V., Patrick R. Bentley, and James Lee Ray. 2013. 'Ally Provocateur: Why Allies Do Not Always Behave'. Journal of Peace Research 50(2):47-58.

Boix, Carles, Michael Miller, and Sebastian Rosato. 2013. 'A Complete Data Set of Political Regimes, 1800-2007'. Comparative Political Studies 46(12):1523-54.

Bueno de Mesquita, Bruce, Alastair Smith, Randolph M. Siverson, and James D. Morrow. 2003. The Logic of Political Survival. Cambridge, MA: MIT Press.

Bueno de Mesquita, Bruce, James D. Morrow, Randolph M. Siverson, and Alastair Smith. 1999. 'An Institutional Explanation for the Democratic Peace'. American Political Science Review 93(4):791-807.

Bueno De Mesquita, Bruce, and Randolph M. Siverson. 1995. 'War and the Survival of Political Leaders A Comparative Study of Regime Types and Political Accountability'. American Political Science Review 89(4):841-55.

Cameron, A. Colin, and Pravin K. Trivedi. 2005. Microeconometrics: Methods and Applications. Cambridge: Cambridge University Press.

Chapman, Terrence. 2007. 'International Security Institutions, Domestic Politics, and Institutional Legitimacy'. Journal of Conflict Resolution 51(1):134-66.

Choi, Ajin. 2003. 'The Power of Democratic Cooperation'. International Security 28(1):142-53.

Choi, Ajin. 2004. 'Democratic Synergy and Victory in War, 1816-1992'. International Studies Quarterly 48:663-82.

Choi, Ajin. 2012. 'Fighting to the Finish: Democracy and Commitment in Coalition War'. Security Studies 21(4):624-53.

Clarke, Kevin, and Randall Stone. 2008. 'Democracy and the Logic of Political Survival'. American Political Science Review 102(2):387-92.

Conybeare, John A.C. 1992. 'A Portfolio Diversification Model of Alliances: The Triple Alliance and Triple Entente, 1879-1914'. Journal of Conflict Resolution 36(1):53-85.

Conybeare, John A.C. 1994. 'Arms Versus Alliances: The Capital Structure of Military Enterprise'. Journal of Conflict Resolution 38(2):215-35.

Crabtree, Charles, and Christopher J. Fariss. 2015. 'Uncovering Patterns Among Latent Variables: Human Rights and De Facto Judicial Independence'. Research \& Politics 2(3):1-9.

Cranmer, Skyler J., Bruce A. Desmarais, and Justin H. Kirkland. 2012. 'Toward a Network Theory of Alliance Formation'. International Interaction 38(3):295-324.

Crescenzi, Mark J.C., and Andrew J. Enterline. 2001. 'Time Remembered: A Dynamic Model of Interstate Interaction'. International Studies Quarterly 45(3):409-31.

Crescenzi, Mark J.C., Jacob D. Kathman, Katja B. Kleinberg, and Reed M. Wood. 2012. 'Reliability, Reputation, and Alliance Formation'. International Studies Quarterly 56(2):259-74.

Croco, Sarah E. 2011. 'The Decider's Dilemma: Leader Culpability, War Outcomes, and Domestic Punishment'. American Political Science Review 105(3):457-77.

Downes, Alexander. 2009. 'How Smart and Tough Are Democracies?: Reassessing Theories of Democratic Victory in War'. International Security 33(4):9-51.

Downs, Anthony. 1957. An Economy Theory of Democracy. New York, NY: Harper and Row.

Downs, George, and David M. Rocke. 1995. Optimal Imperfection: Domestic Uncertainty and Institutions in International Relations. Princeton, NJ: Princeton University Press.

Doyle, Michael. 1997. Ways of War and Peace: Realism, Liberalism, and Socialism. New York, NY: Norton.

Efron, Bradley. 1983. 'Estimating the Error rate of a Prediction Rule: Improvement on Cross-Validation'. Journal of the American Statistical Association 78(382):316-31.

Epstein, David L., Robert Bates, Jack Goldstone, Ida Kristensen, and Sharyn O’Halloran. 2006. 'Democratic Transitions'. American Journal of Political Science 50(3):551-69.

Fazal, Tanisha. 2007. State Death: The Politics and Geography of Conquest, Occupation, and Annexation. Princeton, NJ: Princeton University Press.

Filson, Darren, and Suzanne Werner. 2004. 'Bargaining and Fighting: The Impact of Regime Type on War Onset, Duration, and Outcome'. American Journal of Political Science 48(2):296-313. 
Gartner, Scott Sigmund, and Randolph M. Siverson. 1996. 'War Expansion and War Outcome'. Journal of Conflict Resolution 40(1):1-15.

Gartzke, Erik. 2001. 'Democracy and the Preparation for War: Does Regime Type Affect States' Anticipation of Casualties?'. International Studies Quarterly 45(3):467-84.

Gartzke, Erik A., and Alex Weisiger. 2014. 'Under Construction: Development, Democracy, and Difference as Determinants of the Systemic Liberal Peace'. International Studies Quarterly 58(1):130-45.

Gartzke, Erik, and Alex Weisiger. 2013. 'Fading Friendships: Alliances, Affinities and the Activation of International Identities'. British Journal of Political Science 43(1):25-52.

Gartzke, Erik A., and Kristian Skrede Gleditsch. 2004. 'Regime Type and Commitment: Why Democracies are Actually Less Reliable Allies'. American Journal of Political Science 48(3):775-95.

Gibler, Douglas, and Meredith Reid Sarkees. 2004. 'Measuring Alliances: The Correlates of War Formal Interstate Alliance Dataset, 1816-2000'. Journal of Peace Research 41(2):211-22.

Goemans, Hein E., and Giacomo Chiozza. 2011. Leaders and International Conflict. Cambridge: Cambridge University Press.

Gordon, Phillip I. 2005. Permutation, Parametric, and Bootstrap Tests of Hypotheses. New York: Springer-Verlag.

Hill, Daniel W. Jr., and Zachary M. Jones. 2014. 'An Empirical Evaluation of Explanations for State Repression’. American Political Science Review 108(3):661-87.

Hurd, Ian. 1999. 'Legitimacy and Authority in International Politics'. International Organization 53(2):397-408.

Ikeda, Maki, and Atsushi Tago. 2014. 'Winning Over Foreign Domestic Support for Use of Force: Power of Diplomatic and Operational Multilateralism'. International Relations of the Asia-Pacific 14(2):303-24.

Kant, Immanuel. 1972(1795). Perpetual Peace: A Philosophical Essay. New York, NY: Garland.

Kimball, Anessa L. 2010. 'Political Survival, Policy Distribution, and Alliance Formation'. Journal of Peace Research 47(4):407-19.

King, Gary. 1989. 'Event Count Models for International Relations: Generalizations and Applications'. International Studies Quarterly 33(2):123-47.

Koch, Michael, and Scott Sigmund Gartner. 2005. 'Casualties and Constituencies: Democratic Accountability, Electoral Institutions, and Costly Conflicts'. Journal of Conflict Resolution 49:874-94.

Lai, Brian, and Dan Reiter. 2000. 'Democracy, Political Similarity, and International Alliances, 1816-1992'. Journal of Conflict Resolution 44(2):203-27.

Lake, David A. 1992. 'Powerful Pacifists: Democratic States and War'. American Political Science Review 86(1):24-37.

Leeds, Brett Ashley. 2003. 'Alliance Reliability in Times of War: Explaining State Decisions to Violate Treaties'. International Organization 57(4):801-27.

Leeds, Brett Ashley, and David R. Davis. 1997. 'Domestic Political Vulnerability and International Disputes'. Journal of Conflict Resolution 41(6):814-34.

Leeds, Brett Ashley, Jeffrey M. Ritter, Sara McLaughlin Mitchell, and Andrew G. Long. 2002. 'Alliance Treaty Obligations and Provisions, 1815-1944'. International Interactions 28(3):237-60.

Leeds, Brett Ashley, Michaela Mattes, and Jeremy S. Vogel. 2009. 'Interests, Institutions, and the Reliability of International Commitments'. American Journal of Political Science 53(2):461-76.

Levy, Jack. 1993. 'The Diversionary Theory of War: A Critique'. In Manus I. Midlarsky (ed.), Handbook of War Studies. 259-88. Ann Arbor, MI: University of Michigan Press.

Mackie, Gerry. 2003. Democracy Defended. New York, NY: Cambridge University Press.

Madison, James. 1961. 'Federalist 51'. In Clinton Rossiter (ed.), The Federalist Papers, 317-321. New York, NY: New American Library.

Maoz, Zeev. 2005. 'Dyadic MID Dataset (DYMID) Dataset (version 2.0)'. Computer File. Available at http://psfaculty.ucdavis.edu/zmaoz/dyadmid.html, accessed 5 January 2010.

Marshall, Monty G., and Keith Jaggers. 2007. 'Polity IV Project: Dataset Users' Manual'. Available at www.systemicpeace.org/polity, accessed 3 December 2013. 
Marshall, Monty, Keith Jaggers, and Ted R. Gurr. 2003. 'Political Regime Characteristics and Transitions, Polity IV Dataset'. Available at http://www.cidcm.umd.edu/inscr/polity/, accessed 3 December 2013.

Martin, Lisa L., and Beth A. Simmons. 1998. 'Theories and Empirical Studies of International Institutions'. International Organization 52(4):729-57.

Mattes, Michaela. 2012. 'Reputation, Symmetry, and Alliance Design'. International Organization 6(4):679-707.

Meernik, James D., and Peter Waterman. 1996. 'The Myth of the Diversionary Use of Force by American Presidents'. Political Research Quarterly 49(3):573-90.

Morgenthau, Hans. 1978. Politics Among Nations. New York, NY: Knopf.

Morrow, James D. 1991. 'Alliances and Asymmetry: An Alternative to the Capability Aggregation Model of Alliances'. American Journal of Political Science 35(4):904-33.

Przeworski, Adam, and Fernando Limongi. 1997. 'Modernization: Theories and Facts'. World Politics 49(2):155-83.

R Development Core Team. 2014. R: A Language and Environment for Statistical Computing. Vienna, Austria: R Foundation for Statistical Computing ISBN 3-900051-07-0. Available at http://www.R-project.org.

Reiter, Dan, and Allan C. Stam. 1998. 'Democracy and Battlefield Military Effectiveness'. Journal of Conflict Resolution 42(3):259-77.

Reiter, Dan, and Allan C. Stam. 2008. 'Democracy, Peace, and War'. In Barry Weingast and Donald Wittman (eds), The Oxford Handbook of Political Science. Oxford: Oxford University Press. doi:10.1093/oxfordhb/9780199548477.003.0048.

Reiter, Dan, and Allan C. Stam. 2002. Democracies at War. Princeton, NJ: Princeton University Press.

Reiter, Dan, Allan C. Stam, and Michael C. Horowitz. 2014. 'A Revised Look at Interstate Wars, 1816-2007'. Journal of Conflict Resolution, doi:10.1177/0022002714553107.

Russett, Bruce M. 1971. 'An Empirical Typology of International Military Alliances'. Midwest Journal of Political Science 15(2):262-89.

Russett, Bruce M. 1990. Controlling the Sword: The Democratic Governance of National Security. Cambridge, MA: Harvard University Press.

Russett, Bruce. 1993. Grasping the Democratic Peace: Principles for a Post-Cold War World. Princeton, NJ: Princeton University Press.

Shadish, William R. 2010. 'Campbell and Rubin: A Primer and Comparison of Their Approaches to Causal Inference in Field Settings'. Psychological Methods 12(1):3-17.

Simon, Michael W., and Erik Gartzke. 1996. 'Political System Similarity and the Choice of Allies: Do Democracies Flock Together or Do Opposites Attract?'. Journal of Conflict Resolution 40(4):617-35.

Singer, J. David, and Melvin Small. 1966. 'Formal Alliances, 1815-1939: A Quantitative Description'. Journal of Peace Research 3(1):1-31.

Siverson, Randolph M., and Juliann Emmons. 1991. 'Birds of a Feather: Democratic Political Systems and Alliance Choices in the Twentieth Century'. Journal of Conflict Resolution 35(2):285-306.

Smith, Alastair. 1995. 'Alliance Formation and War'. International Studies Quarterly 39(4):405-25.

Stata Corporation. 2010. Stata 11.0. College Station, TX: Stata Corporation.

Sullivan, Patricia Lynne, and Scott Sigmund Gartner. 2006. 'Disaggregating Peace: Domestic Politics and Dispute Outcomes'. International Interactions 32(1):1-25.

Tago, Atsushi. 2005. 'Determinants of Multilateralism in US Use of Force: State of Economy, Election Cycle, and Divided Government'. Journal of Peace Research 42(5):585-604.

Tago, Atsushi. 2009. 'When are Democratic Friends Unreliable? The Unilateral Withdrawal of Troops from the "Coalition of the Willing". Journal of Peace Research 46(2):219-34.

Tago, Atsushi, and Maki Ikeda. 2015. "An "A" for Effort: Experimental Evidence on UN Security Council Engagement and Support for US Military Action in Japan'. British Journal of Political Science 45(2):391-410.

Valentino, Benjamin A., Paul K. Huth, and Sarah E. Croco. 2010. 'Bear Any Burden? How Democracies Minimize the Costs of War'. Journal of Politics 72(2):528-44. 
Voeten, Erik. 2005. 'The Political Origins of the UN Security Council's Ability to Legitimize the Use of Force'. International Organization 59(3):527-57.

Walt, Stephen. 1987. The Origins of Alliances. Ithaca, NY: Cornell University Press.

Waltz, Kenneth N. 1979. Theory of International Politics. Boston, MA: McGraw Hill.

Ward, Michael D., Brian D. Greenhill, and Kristin M. Bakke. 2010. 'The Perils of Policy by p-Value: Predicting Civil Conflicts'. Journal of Peace Research 47(4):1-13.

Weeks, Jessica, and Dara Cohen. 2007. 'Red Herrings? Non-State Actors and Militarized Interstate Disputes'. Paper presented at the 48th Annual Meetings of the International Studies Association, April 3-6, San Francisco, CA.

Weitsman, Patricia A. 2004. Dangerous Alliances Proponents of Peace, Weapons of War. Stanford, CA: Stanford University Press.

Wright, Thorin M. 2014. 'Territorial Revision and State Repression'. Journal of Peace Research 51(3):375-87.

Wright, Thorin M., and Paul F. Diehl. 2014. 'Unpacking Territorial Disputes Domestic Political Influences and War'. Journal of Conflict Resolution, doi:10.1177/0022002714553105.

Zacher, Mark. 2001. 'The Territorial Integrity Norm: International Boundaries and the Use of Force'. International Organization 55(2):215-50. 